\title{
Partial Glycinergic Denervation Induces Transient Changes in the Distribution of a Glycine Receptor-associated Protein in a Central Neuron
}

\author{
Tania Seitanidou, Marie-Anne Nicola, Antoine Triller, and Henri Korn \\ Laboratoire Neurobiologie Cellulaire, INSERM U261, Département des Biotechnologies, Institut Pasteur, 75724 Paris \\ Cedex 15, France
}

The effect of partial glycinergic denervation on the cellular distribution of the $93 \mathrm{kDa}$ peripheral polypeptide associated with the glycine receptor was studied at the level of the teleost Mauthner cell, an identified neuron of the goldfish brain (Carassius auratus). Previous studies using monoclonal antibodies raised against purified glycine receptors and immunoperoxidase staining have shown that these proteins are localized in clusters on the entire surface of this neuron. Specifically, the $93 \mathrm{kDa}$ polypeptide was situated only on the cytoplasmic side of the postsynaptic membrane facing active zones.

Unilateral electrolytic lesions of the vestibular complex caused the degeneration of some glycinergic afferents to this neuron. When the first signs of this response appeared, $3 \mathrm{~d}$ after the surgery, there was also a change in the ultrastructural distribution of the $93 \mathrm{kDa}$ polypeptide in the deafferented cell. The synaptic protein apposed to degenerating axons did not spread onto adjacent extrasynaptic membranes, and it disappeared a few hours after the disruption of its presynaptic element. At the same time, a cytoplasmic immunoreactivity appeared as randomly distributed clusters in the deafferented Mauthner cell; these aggregates, not seen in control preparations, were never found inside membrane-bound organelles. In some preparations these clusters were localized along arrays at a relatively constant distance from the plasma membrane. The intracellular immunoreaction product was found in the soma and the initial part of the dendrites, gradually decreasing in number and intensity toward the extremities of these processes. At later postoperative stages, 10-15 d after surgery, the 93 kDa immunoreactivity remained only at postsynaptic membranes facing intact terminals. Similar alterations following denervation were observed in reticular neurons, at the level at which degenerating presynaptic terminals were also detected.

In contrast, continuous 3-d blockade of synaptic transmission by strychnine, an antagonist of the glycine receptor,

\footnotetext{
Received Apr. 24, 1991; revised June 25, 1991 ; accepted Aug. 14, 1991.

We thank H. Betz and his colleagues (Zentrum für Molekulare Biologie, Heidelberg) for providing the monoclonal antibodies, and P. Caramelle for technical assistance and photography. T.S. is the recipient of CEE Fellowship Contract SC1000304. This work was supported by a grant from DRET (No. 90.069).

Correspondence should be addressed to Antoine Triller, Laboratoire Neurobiologie Cellulaire, INSERM U261, Institut Pasteur, 25 Rue du Dr. Roux, 75724 Paris Cedex 15, France.

Copyright (C) 1992 Society for Neuroscience $0270-6474 / 92 / 120116-16 \$ 05.00 / 0$
}

had no effect on either the distribution of the surface receptor clusters, or the $93 \mathrm{kDa}$ peripheral protein linked to these receptors.

Taken together, our results suggest that the ultrastructural distribution of the glycine receptor complex is regulated by "trophic" factors rather than by transmitter-evoked synaptic activity.

At most chemical synapses, cytoplasmic proteins are associated with receptor molecules. The best-documented case is that of the $43 \mathrm{kDa}$ protein that is linked to the nicotinic receptor at the neuromuscular junction (Froehner et al., 1981; St.John et al., 1982; Sealock et al., 1984; Bridgman et al., 1987). It has been recently confirmed that this protein induces the clustering of ACh receptors when coexpressed with it in oocytes (Froehner et al., 1990), or in transfected fibroblast cell lines (Phillips et al., 1991; see also Cartaud et al., 1981; Rousselet et al., 1982; Burden et al., 1983; Peng and Froehner, 1985; Bloch and Froehner, 1987), implying that its function does not require the presence of nerve inputs per se. However, despite extensive studies of the effects of denervation on peripheral nicotinic receptor (Jacob and Berg, 1987, 1988; Sargent and Pang, 1988; for reviews, see also Fambrough, 1979; Schuetze and Role, 1987), nothing is known about the possiblc influcnce of nerve injury on the cellular distribution of the $43 \mathrm{kDa}$-associated protein. Such is also the case for anchoring proteins in the CNS.

Until recently, morphological data following selective denervations have been difficult to obtain in the vertebrate brain, for two reasons. One is that central pathways are intermingled, and few of them can be severed in isolation. The second is the lack of specific antibodies, which are required for detailed immunocytochemical studies and ultrastructural analysis of central synapses. An exception is the Mauthner (M)-cell inhibitory network, part of which belongs to the vestibulo-vestibular commissural pathway (Zottoli and Faber, 1980; Triller and Korn, 1981), that has been characterized electrophysiologically (Faber and Korn, 1973; Korn and Faber, 1976). Its terminals are glycinergic (Faber and Korn, 1980, 1988), and their effect on the M-cell is blocked by strychnine (Faber and Korn, 1988).

The glycinc receptor (GlyR) is a ligand-gated ion channcl that mediates Cl-dependent inhibitory currents in the CNS (Korn et al., 1990). It is antagonized by strychnine (reviewed in Korn and Faber, 1990). This property has been used to purify the receptor complex from the mammalian spinal cord and to demonstrate that the protein contains three polypeptides of 48,58 , and $93 \mathrm{kDa}$. The first two are transmembrane polypeptides 
(reviewed in Betz and Becker, 1988), whereas the $93 \mathrm{kDa}$ subunit is a nonglycosylated peripheral membrane protein (Schmitt et al., 1987). Among the monoclonal antibodies (mAbs) raised against the purified rat GlyR, the $4 \mathrm{a} \mathrm{mAb}$ specifically binds to the $48 \mathrm{kDa}$ or $\alpha$-subunit, while the $5 \mathrm{a}$ and $7 \mathrm{a}$ ones bind to the $93 \mathrm{kDa}$ protein (Pfeiffer et al., 1984).

The $48 \mathrm{kDa}$ subunit, which bears the antagonistic binding site (Pfeiffer et al., 1984), and the $93 \mathrm{kDa}$ subunit have been detected at restricted sites facing presynaptic active zones in the adult brains of the rat (Triller et al., 1985; Altschuler et al., 1986; Van den Pol and Gorcs, 1988) and goldfish (Triller et al., 1986; Seitanidou et al., 1988, 1991). Furthermore, Western blot analysis has shown that the antibodies recognize only antigens of similar molecular weight in the rat and goldfish brain and that they are colocalized regionally with strychnine-binding sites (Becker et al., 1991).

Taking advantage of these probes, we have investigated the role of innervation on the ultrastructural distribution of the M-cell postsynaptic $93 \mathrm{kDa}$ polypeptide. Our results indicate that even a mild denervation results in striking alterations of this protein's cytoplasmic localization that are different from those reported in the neuromuscular junction. In contrast, a chronic and massive block of synaptic activity has no detectable influence on this protein and the associated glycine receptors.

Parts of these results, which do not support the concept that synaptic transmission controls the stability of junctional receptors, have been presented briefly in a previous communication (Seitanidou et al., 1990).

\section{Materials and Methods}

Our experiments were based on the notion that glycinergic commissural interneurons innervate both Mauthner cells in the goldfish brainstem (Triller and Korn, 1981).

Electrolytic lesions. Adult goldfish (Carassius auratus) $13-15 \mathrm{~cm}$ in body length were used. They were anesthetized with $0.30 \% 3$-aminobenzoic acid ethyl ester (Sigma). When gill movement ceased, they were transferred to a surgical chamber where $0.20 \%$ of the same anesthetic was recirculated through the mouth and over the gills during surgery.

Once a fish was immobilized, the cerebellum and the anterior part of the vagal lobe were exposed. The cerebellum was pushed forward and the dura mater over the fourth ventricle was removed. During this procedure, both otic capsules remained intact but the semicircular canals of the lesioned site were often disrupted. An insulated tungsten electrode (tip diameter, $<1 \mu \mathrm{m}$ ) was then introduced in the medulla, at the most anterior part of the right cerebellar crest. A positive current of 0.005 $0.05 \mathrm{~mA}$ was applied for $15-30 \mathrm{sec}$, with the expectation that lesions produced by similar anodal intensities are reproducible in size and shape (Moore, 1981). The electrode was removed and the cerebellum was returned to its original position. A piece of parafilm slightly larger than the size of the hole was placed on the skull, sealed around its edge with acrylic glue, and covered with dental cement. The fish was then respired continuously with tap water for $15 \mathrm{~min}$ and returned to the aquarium. After variable survival times, the location of the lesion and its extent were verified in transverse thick sections $(80 \mu \mathrm{m})$ embedded in araldite (see below).

As summarized in Table 1, brains from 31 lesioned fish, 10 intact ones, and 5 sham-operated control animals were processed for electron microscopy. The ultrastructural distribution of the $93 \mathrm{kDa}$ protein was analyzed after different postoperative intervals of 2-15 d, as listed in Table 1.

Chronic block of glycine receptors by strychnine. As in previous studies (Faber and Korn, 1982, 1988), glycinergic receptors were functionally blocked by injecting intramuscularly $5 \mu \mathrm{g} / \mathrm{gm}$ body weight of strychnine sulfate diluted in $0.9 \%$ saline solution. The animals received a dose of strychnine every $6 \mathrm{hr}$ for 1-3 d. A total of 24 adult goldfish were treated in this manner: 7 of them were used to visualize the localization of the $93 \mathrm{kDa}$ polypeptide with electron microscopy, and 8 were used to analyze the $\alpha$-subunit distribution. The remaining 9 were used for elec- trophysiological recordings in order to determine if in those conditions the antagonist had reduced or suppressed the $\mathbf{M}$-cell responses to synaptically released glycine. Three of them were investigated 5-6 hr after a unique dose, the remaining 4 (two of which were recorded on both $\mathrm{M}$-cells) were subjected to a chronic treatment for $3 \mathrm{~d}$ before physiological analysis.

Electrophysiological recordings. Fish treated with strychnine as described above were anesthetized with MS222 and immobilized with Flaxedil ( $1 \mu \mathrm{g} / \mathrm{gm}$ body weight). The preparation and basic physiological techniques were similar to those employed before (Korn and Faber, 1976). The M-cell was identified on the basis of its stereotyped response to antidromic stimulations of its axon in the spinal cord (Furshpan and Furukawa, 1962), and extra- or intracellular activities were monitored with low-resistance (2-5 M $\Omega$ ) microelectrodes. The latter were filled with $\mathrm{K}$-acetate or with $3 \mathrm{M} \mathrm{KCl}$ in order to maximize and therefore detect possible inhibitory postsynaptic potentials (IPSPs) since in this neuron resting membranes at $\mathrm{Cl}^{-}$equilibrium potentials are close to each other (Furukawa and Furshpan, 1963). At the end of some recording sessions, the resting membrane conductance was measured on current traces evoked by de- and hyperpolarizing command pulses and obtained as previously (Faber and Korn, 1986) with single-electrode voltage-clamp recordings (Axon Instruments) with chopping rates in the range of $16-33 \mathrm{~Hz}$.

Immunocytochemical techniques. Animals were anesthetized as above and injected intramuscularly with $0.5 \mathrm{ml}$ Flaxedil. For electron microscopy, they were perfused through the heart with a mixture of $4 \%$ paraformaldehyde (PFA) and $0.1 \%$ glutaraldehyde in $120 \mathrm{~mm}$ phosphate buffer (PB), pH 7.4, for 20 min, followed by $4 \%$ PFA alone. The brains were removed, postfixed overnight in $4 \%$ PFA in PB, and sectioned with a Vibratome. The slices $(80 \mu \mathrm{m})$ were reacted with $0.1 \mathrm{~mm}$ lysine for $30 \mathrm{~min}$ and were incubated overnight at room temperature in the 7a mAb diluted 1:100 in phosphate-buffered saline (PBS). This antibody recognizes different antigenic sites on the $93 \mathrm{kDa}$ polypeptide (Pfeiffer et al., 1984; Triller et al., 1985). The binding sites were detected as described elsewhere (Seitanidou et al., 1988) using the ABC (Vectastain kit) method (Hsu et al., 1981). The avidin-biotin-HRP complex was revealed after addition of $0.03 \%$ diaminobenzidine tetrachloride (DAB) in $0.05 \mathrm{M}$ Tris, $\mathrm{pH} 7.4$, and $\mathrm{H}_{2} \mathrm{O}_{2}$. The formation of the HRP dark reaction product was controlled under light microscopic observation. The tissue was then postfixed in buffered $2 \% \mathrm{OsO}_{4}$, dehydrated in graded ethanol, and flat-embedded in Araldite. Sections with a silver interfercnce color were counterstained with lead citrate and viewed with a Philips EM10 electron microscope.

For light microscopy, the fish were only perfused with 4\% PFA in $120 \mathrm{~mm} \mathrm{~PB}, \mathrm{pH} \mathrm{7.4,} \mathrm{for} 15 \mathrm{~min}$. After dissection, the brains were immersed in $40 \%$ sucrose in PBS overnight. Thick $60 \mu \mathrm{m}$ sections were collected in $0.25 \%$ ammonium chloride in PBS, to block free aldehyde groups. After washing in PBS, the slices were put through a series of ethanol solutions at $25 \%, 40 \%, 50 \%, 40 \%$, and $25 \%$ in order to increase immunoreactivity. The tissue was allowed to react overnight with the $4 \mathrm{a} \mathrm{mAb}$ that specifically recognizes the $48 \mathrm{kDa}$ polypeptide of the GlyR (Pfeiffer et al., 1984). The antibody was diluted in PBS (1:250) in the presence of $0.12 \%$ gelatin and $0.25 \%$ Triton X-100. After extensive rinsing with PBS, the sections were successively incubated with a biotinylated horse anti-mouse IgG and biotin-streptavidine-fluorescein complex (Amersham), diluted in PBS (1:200), for $2 \mathrm{hr}$. The slices were mounted with Mowiol (Hoechst, Frankfurt) and examined with a confocal scanning laser microscope (CSLM; Phoibos 1000, Molecular Dynamics, Sunnyvale, CA, USA). We obtained high-resolution digitized images, with a pixel size of $0.15 \mu \mathrm{m}$, by using a $100 \times$ objective (NA 1.3). The visualization of large surfaces of cell membrane was obtained by look-through projections (Carlsson and Aslund, 1987) of consecutive digital sections.

Morphometrical data. The ratio of degenerating somatic fibers to the total number of presynaptic afferents was measured on random ultrathin sections from three experimental animals, $3 \mathrm{~d}$ after lesion, using the M-cell's axon cap as a landmark for this neuron's soma. Endings still in contact with the $\mathrm{M}$-cell membrane, or within a maximum distance of $3 \mu \mathrm{m}$ of it, were counted in order to guarantee that the profiles were indeed presynaptic to this cell.

The proportion of intact small-vesicle boutons (SVBs) apposed to 93 $\mathrm{kDa}$-immunoreactive postsynaptic densities versus the total number of contacts was calculated from surface sections of three deafferented M-cells, after a survival time of 3-5 d, and on four animals injected with strychnine for $3 \mathrm{~d}$. 
Table 1. Presynaptic degeneration pattern and distribution of the $93 \mathrm{kDa}$ polypeptide in control and in deafferented M-cell

\begin{tabular}{|c|c|c|c|c|c|c|c|c|}
\hline \multirow{3}{*}{$\begin{array}{l}\text { Num- } \\
\text { ber of } \\
\text { fish } \\
\text { ( } 46 \\
\text { total) }\end{array}$} & \multirow{3}{*}{$\begin{array}{l}\text { Survival } \\
\text { time }\end{array}$} & \multirow{3}{*}{$\begin{array}{l}\text { Lesion local- } \\
\text { ization in VN }\end{array}$} & \multicolumn{2}{|c|}{$\begin{array}{l}\text { Degenerating } \\
\text { profiles }\end{array}$} & \multicolumn{4}{|l|}{ 93kd-IR } \\
\hline & & & \multirow[b]{2}{*}{$\mathrm{S}$} & \multirow[b]{2}{*}{$\mathrm{NC}$} & \multirow{2}{*}{$\begin{array}{l}\text { Intra- } \\
\text { cellular }\end{array}$} & \multicolumn{3}{|c|}{ Plasma membrane } \\
\hline & & & & & & $\mathrm{N}$ & $\mathrm{D}$ & $\mathrm{F}$ \\
\hline 2 & $2 \mathrm{~d}$ & + & - & - & - & + & - & \\
\hline 3 & $3 d$ & + & + & + & + & + & + & + \\
\hline 4 & $3 d$ & + & - & + & + & + & - & - \\
\hline 6 & $4 d$ & + & - & + & + & + & - & - \\
\hline 5 & $5 d$ & + & - & + & + & + & - & - \\
\hline 3 & $6 \mathrm{~d}$ & + & - & + & + & + & - & - \\
\hline 2 & $7 d$ & + & - & - & + & + & - & - \\
\hline 3 & $10 \mathrm{~d}$ & + & - & - & - & + & - & - \\
\hline 3 & $15 d$ & + & - & - & - & + & - & - \\
\hline 2 & $3 d$ & sham-operated & - & - & - & + & - & - \\
\hline 3 & $4 d$ & sham-operated & - & - & - & + & - & - \\
\hline 10 & & not operated & - & - & - & + & - & - \\
\hline
\end{tabular}

A total of 46 animals were used: 31 with unilaterally lesioned vestibular nuclei, 5 sham-operated, and 10 unoperated fish were analyzed. In these selected animals, the lesion was precisely localized in the vestibular nuclei at the level of the M-cell. A representative example of such lesion is illustrated in Figure $1 \mathrm{~A}$. Two categories of degenerating profiles were observed: endings synapsing (S) with the M-cell, and fibers not in contact (NC) with it. These axons were in the M-cell's synaptic bed, at a distance less than $10 \mu \mathrm{m}$ from the plasma membrane. The 93kd-IR was intracellular or assucialed with plasmalemma. In the latter category, the 93kd-IR was apposed to normal (N) or degenerating (D) endings, or facing free (F) extracellular space.

Electron microscopy sections obtained in the same conditions were used to estimate the length of the postsynaptic membrane labeling. The extent of the HRP reaction product was directly measured from micrographs $(42,000 \times)$. The surface area of the GlyR clusters labeled with the $4 \mathrm{a}$ mAb was quantified on confocal micrographs. All these measurements were carried out using a digitizing pad connected to a microcomputer.

\section{Results}

\section{Behavioral changes in operated animals}

Immediately after recovery from anesthesia, all fish with unilaterally damaged vestibular nuclei were unable to swim along a straight line. They swam with disordered movements in an arc bent toward the lesion. When still, they usually remained on the affected side, near the bottom of the tank. Two days after surgery, they exhibited normal posture and equilibrium at rest, and they began to swim normally at $4 \mathrm{~d}$. Finally, their swimming and resting behavior had completely recovered by the tenth postoperative day. In contrast, the startle reflex provoked by tapping on the aquarium was always elicited, even immediately after the operation.

Sham-operated control fish had normal swimming responses even though they remained immobile at the bottom of the aquarium during the first postoperative days.

\section{Unilateral lesion of vestibular complex and degeneration pattern}

In every operated animal selected for this study (Table 1), the lesion was restricted to the vestibular complex and affected all four vestibular nuclei. Its maximum dimensions never exceeded $800 \mu \mathrm{m}$ in the longitudinal and $600 \mu \mathrm{m}$ in the dorsoventral and lateromedial axes.

A representative photomicrograph of a transverse thick section at the level of the lesion obtained $3 \mathrm{~d}$ after surgery is shown in Figure $1 A$. Its shape was ovoid, extending up to $640 \mu \mathrm{m}$ in the rostrocaudal and $450 \mu \mathrm{m}$ in the horizontal and vertical axes. The central cavity, where the tissue was completely destroyed, was no more than $200 \mu \mathrm{m}$ in diameter (in this and other preparations as well). Damaged tissue, encircled by a narrow rim of gliosis, was present $360 \mu \mathrm{m}$ posterior to the M-cell's lateral dendrite, disappearing at the level of the tip of its ventral dendrite. In all material selected for the present study, the lesion was located in the vestibular complex, either just above the secondary gustatory and descending trigcminal tracts (Fig. $1 A, B$ ) or, more medially, between the ventricle and the outer limit of the brain (not shown).

As schematized in Figure $1 B$, the damaged area was situated at the entrance of the eighth nerve above the descending trigeminal tract and close to the lateral dendrite of the M-cell. Thus, it is possible that in some experiments, the current had reached the extremity of this process, which penetrates into the vestibular nuclei in this region. In order to ensure that any morphological changes following surgery were due to causes other than (1) the degeneration of the M-cell itself or (2) the disappearence of the eighth nerve endings, one of the major excitatory inputs of the ipsilateral $\mathrm{M}$-cell, we have restricted our study to the M-cell contralateral to the lesion. However, in three preparations with intact ipsilateral M-cells, identical results were obtained from each command neuron, on either side of the brain.

Three days after the operation, there was an anterograde degeneration of approximately $10 \%$ of the presynaptic afferents at the level of the M-cell soma. As depicted in Figure $1 C$, this phenomenon concerned crossed second-order neurons whose axons project ipsi- and contralaterally, since commissural neurons project bilaterally onto the soma and within the axon cap of both M-cells, to the reticular formation and to the contralateral vestibular complex.

The morphology of the investigated M-cell was compared with that of the unoperated side within those of control animals, 


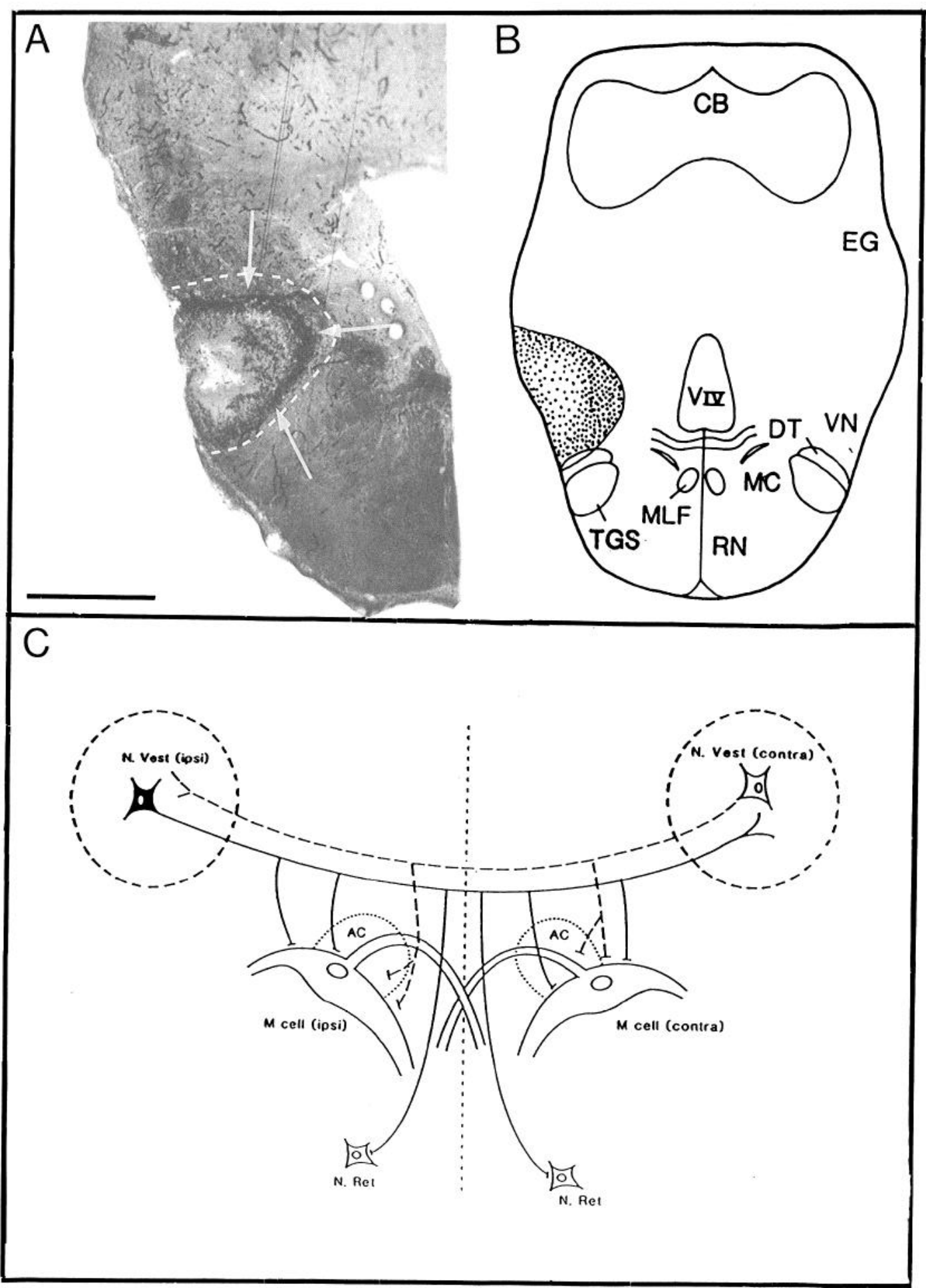

Figure 1. Extent of electrolytic lesions. A, Photomicrograph of a frontal thick $(80 \mu \mathrm{m})$ section along the medial line of the brain, at the level of the vestibular nuclei, showing the lesion (broken line) produced by a cathodal current. Its boundaries are designated by a marked scar (arrows). Scale bar, $500 \mu \mathrm{m}$. B. Transverse section through the same lesion (stippled area), indicating its relation to adjacent structures at the level of the Mauthner cell. $C$, Drawing of commissural glycinergic vestibular neurons synapsing on both M-cells. Vestibular complexes ipsi- [N. Vest (ipsi)] and contralateral $[N$. Vest (contra)] to the lesion are surrounded by dotted circles. Note that efferent processes (solid lines) terminating on both M-cells [M cell (ipsi, contra)] and in the reticular nuclei $(N$. Ret $)$ can be affected by a lesion of the vestibular nucleus. Axons issued by vestibular neurons contralateral to the lesion (broken lines) are also shown. $A C$, axon cap; $C B$, cerebellum; $D T$, descending trigeminal tract; $E G$, eminentia granularis; $M C$, Mauthner cell; $M L F$, medial longitudinal fasciculus; $R N$, reticular nuclei; $T G S$, secondary gustatory tract; VIv, fourth ventricle. 


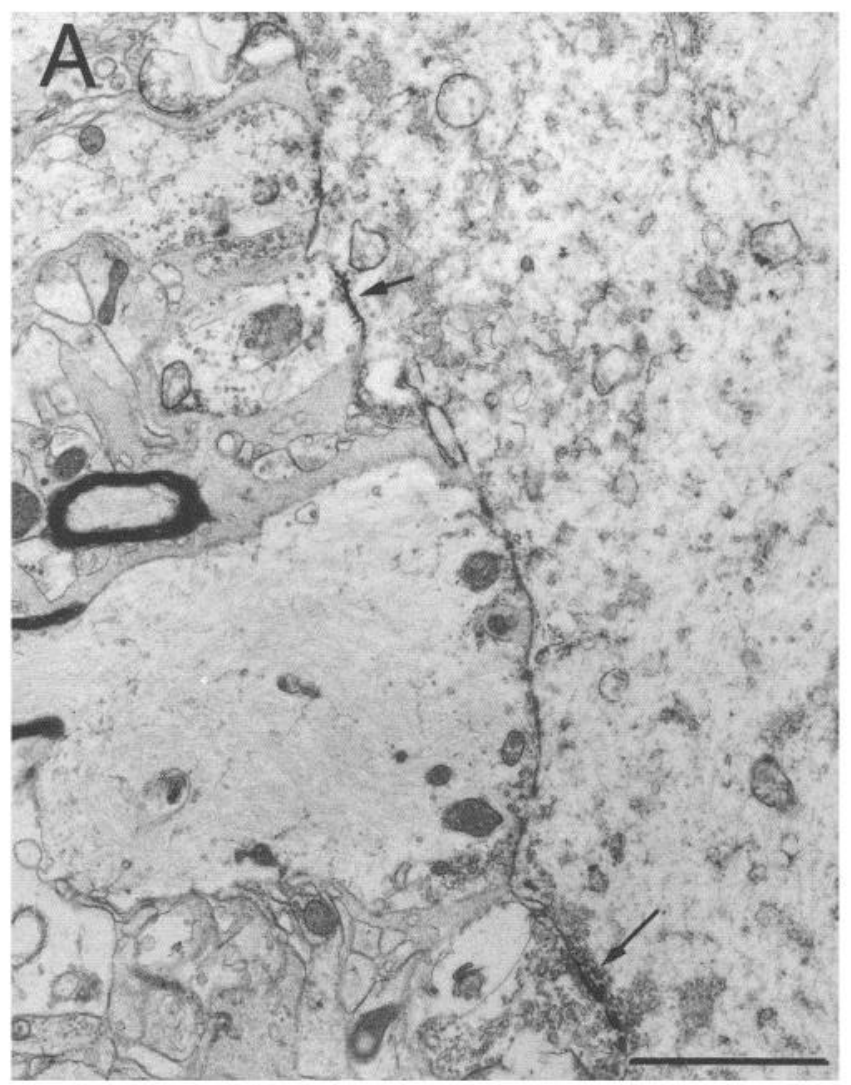

B


Figure 2. Distribution of degenerating profiles on the contralateral M-cell following short postoperative intervals. $A$, Somatic membrane of M-cell from unoperated animals with its typical investment by afferent terminals. Note the labeled postsynaptic differentiations (arrows) of two synaptic contacts. B, Diagram of the distribution of degenerating profiles (shaded area) at the peripheral part of the axon cap, on the soma $(S)$ and on small ventral dendrites $(s V D)$. $C$, Electron micrographs of the M-cell axon cap, $3 \mathrm{~d}$ after a unilateral lesion of the vestibular complex. The peripheral part $(P P)$ of the axon cap is occupied by necrotic debris of fibers (single arrowheads), some of which are surrounded by a lamina of glia (double 
on semithin sections. The shape, size, position, and orientation of its dendrites and axon remained unaltered after denervation. The cell nucleus was always located centrally and somewhat dorsomedially, close to the axon hillock. The nuclear outline was smooth and slightly infolded with no sign of chromatolysis (referenced in Zottoli et al., 1984). At the EM level, the perikaryal and dendritic cytoplasm appeared normal, containing their usual supply of organelles.

\section{Ultrastructural distribution of degenerated axons and fate of synaptic GlyR-associated $93 \mathrm{kDa}$ protein on the $M$-cell}

Previously, in nonoperated fish, the $93 \mathrm{kDa}$ immunoreactivity (93kd-IR) was only detected on synaptic membranes, in apposition to presynaptic release sites (Seitanidou et al., 1988). The immunoreactive product was contiguous to SVBs at the soma (Fig. 2A) and dendrites, and to almost all unmyelinated club endings (UCEs) in the peripheral part of the axon cap.

In control animals $(n=4), 38.5 \pm 3.1 \%$ of the somatic terminals presynaptic to the M-cell were apposed to $93 \mathrm{kDa}$-stained postsynaptic densities. This number decreased $3 \mathrm{~d}$ after lesion $(n=3)$, when only $31.1 \pm 3.1 \%$ of intact endings were in front of immunolabeled membrane. The afferent inputs on the two main dendrites remained unaffected.

As shown in Table 1, degenerating profiles were either in direct contact with their target, or slightly detached from the plasmalemma of the postsynaptic cell. After the third postoperative day, the profiles were rarely still attached to the M-cell. However, scarce degenerating fibers could be observed in the synaptic bed until $7 \mathrm{~d}$ after surgery. The distribution of degenerated terminals was analyzed at $3 \mathrm{~d}$ after lesion. As schematized in Figure $2 B$, the deafferentation of the M-cell was restricted to the soma, the small ventral dendrites, and the peripheral part of the axon cap, whose morphology appeared otherwise normal.

At this time, many dark axonal profiles surrounded by astrocytic processes were found in the peripheral part of the axon cap (Fig. 2C), but never in its central core. The lesioned endings were occasionally in contact with cap dendrites present in this region. As shown in Figure $2 D$, they were also present at the somatic level of the M-cell, either in direct contact with it, or in its synaptic bed at some distance $(2-5 \mu \mathrm{m})$ from the plasmalemma. Dark terminals, still attached to the M-cell (Fig. 2D), were considered as an early sign of degeneration, which preceded complete enwrapment by glial processes.

To determine if the affected afferents were normally apposed to the $93 \mathrm{kDa}$ protein, tissues were immunolabeled with the $7 \mathrm{a}$ mA6. Again, two distinct types of degenerating profiles were observed in the synaptic bed: (1) electron-dense boutons, attached to the M-cell and engulfed by glial cell processes (Fig. $2 D$ ), their corresponding postsynaptic membrane being often immunolabeled (Fig. $2 D$ inset); the staining in front of the degenerating or intact presynaptic endings never outflanked the extrasynaptic membranes; and (2) dark fibers (Fig. 2D) in the synaptic bed, disconnected from the M-cell and completely ensheathed by a lamina of reactive astrocytic cells with numerous cisternae. For a very brief period of time, labeled membrane patches were left deprived of any presynaptic element, apposed to glial processes or to necrotic debris. Randomly distributed glial processes, next to intact terminals, which themselves were apposed to a $93 \mathrm{kd}-\mathrm{IR}$ site, were directly in contact with the $\mathrm{M}$-cell somatic membrane over long distances, a feature never observed in nonoperated animals.

\section{Intracellular $93 \mathrm{kd}-\mathrm{IR}$}

A striking modification of the $93 \mathrm{kDa}$ protein's expression took place in the cytoplasm of the denervated M-cell (Fig. 3A; see also Table 1) under the form of an immunoreactivity on the third day that persisted up to the seventh postoperative day. This staining was concentrated at discrete loci, where it had a circular or oval shape. The cytoplasmic electron-dense precipitate was never observed inside membrane-limited structures such as mitochondria, Golgi and Golgi vesicles, rough and smooth reticulum, or lysosomes. Rather, as revealed by high magnification (Fig. $3 \mathrm{C}$ ), the oxidized DAB at the periphery of the cluster appeared to be related to the cytoskeletal domain and had the form of small dots. Cisternae of agranular endoplasmic reticulum or small vesicles found at the border of the immunoreaction product were stained along their entire perimeter or just a part of it. In this case, the reaction product was associated only with the cytoplasmic surface of their membrane.

Most often clusters of the intracellular $93 \mathrm{kDa}$ protein were randomly distributed in the cytoplasm of the $\mathrm{M}$-cell, in front of any type of presynaptic ending, at varying distances from the plasma membrane, including a juxtaposition (Fig. 3C). However, in three preparations obtained $3 \mathrm{~d}$ or $4 \mathrm{~d}$ postoperatively, they were aligned at $1-5 \mu \mathrm{m}$ from the somatic membrane (Fig. 4). This ordered distribution was almost parallel to the plasmalemma for at least one-third of its perimeter.

In the principal dendrites of the M-cell, where degenerating fibers were not encountered, the cytoplasmic immunoreactivity was nevertheless present (data not shown), although less pronounced than that at the somatic level. In the lateral and in the ventral dendrite of deafferented $M$-cells, the occurrence of precipitate diminished progressively with distance from the soma and was absent at their extremities. In these processes, the cytoplasmic staining was dispersed within the cytoskeletal elements and not associated with the membranes of the endoplasmic reticulum.

The effect of presynaptic deprivation was also studied 10-15 $\mathrm{d}$ after surgery. During this late postoperative interval, degenerating terminals were never present close to the M-cell. The presynaptic bed was comparable to that of the control animals. Nevertheless, terminal-free regions were apparent, with afferent fibers spaced farther apart in the extracellular space. The only antigenic determinant recognized by the $7 \mathrm{a} \mathrm{mAb}$ during this period was that of membranes postsynaptic to afferent processes filled with pleiomorphic vesicles.

As already described, the cytoplasmic $93 \mathrm{kd}-\mathrm{IR}$ was almost exclusively localized on nonmembranous structures. However

arrowheads). In contrast, the central core is unaffected. $D$, Degenerating axonal profiles (arrowheads) in the synaptic bed of and apposed to (arrows) the M-cell soma. Same survival time as in $C$. Note stained glycine receptors (crossed arrow) in front of a terminal bouton undergoing dark degeneration, still in contact with the M-cell. Inset, Higher magnification. $A$, axon; $C C$, central core; $D L$, lateral dendrite; $D V$, ventral dendrite; $n$, nucleus. Scale bars: $A, C$, and $D, 2 \mu \mathrm{m}$; inset, $500 \mathrm{~nm}$. 

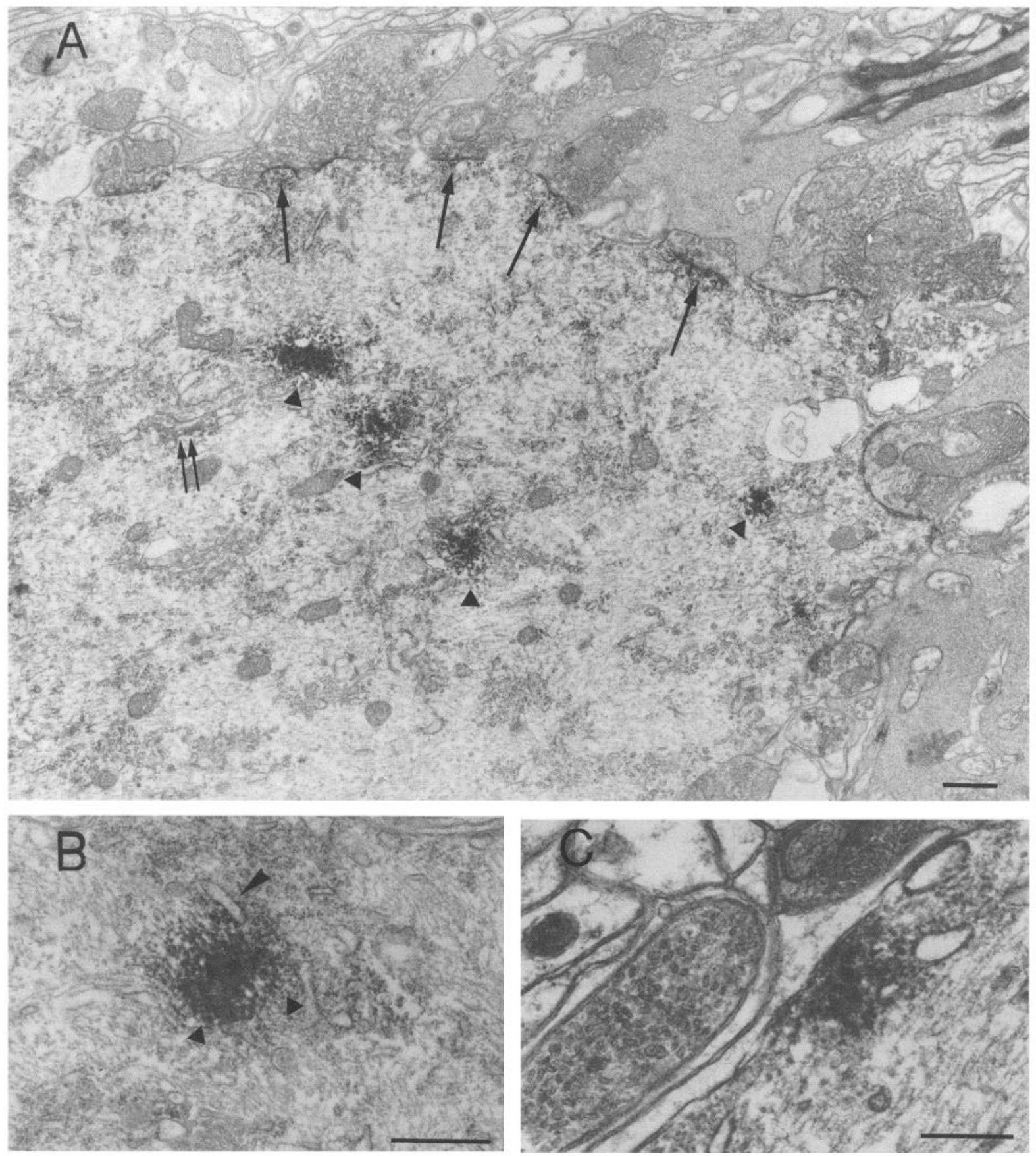

Figure 3. Redistribution of the $93 \mathrm{kd}-\mathrm{IR}$, detected by the $7 \mathrm{a}$ mAb after partial glycinergic denervation of the M-cell soma. A, Appearance of intracellular immunoreactivity at early postoperative intervals. The reaction product (triangles) is in the cytoplasm of the M-cell, $3 \mathrm{~d}$ after surgery. Note the membane labeling (single arrows) in apposition to some presynaptic fibers and the lack of immunoreactivity of the Golgi apparatus (double arrow). B. Higher magnification of the intracellular staining, illustrating that the internal immunoreactivity has a globular shape. There is a dark reaction product at the border of the staining associated with cytoskeletal elements, ribosomes (triangles), and the smooth endoplasmic reticulum (arrowhead). C, Staining in proximity of the M-cell plasmalemma; the extracellular space is occupied by glial cells, which are directly apposed to the plasma membrane. Scale bars: $A$ and $B, 500 \mathrm{~nm} ; C, 250 \mathrm{~nm}$.

in a few instances, it was found near the Golgi apparatus or associated with the cytoplasmic side of peripheral vesicles of the Golgi complex.

\section{Effect of denervation on the reticular neurons}

Cells lying close to the medial and distal parts of the M-cell's ventral dendrite were examined since they are also targets of the commissural vestibular interneurons(Triller and Korn, 1981).
The $93 \mathrm{kDa}$ polypeptide was affected, as described above. At early stages after surgery, the immunoreactivity was present not only at synaptic membranes in front of intact endings, but also in the form of clusters, randomly distributed within the somatic cytoplasm (Fig. 5) and the initial part of the dendrites. Layered astrocytic processes occupied the extracellular space and were occasionally in contact with the noninnervated plasmalemma, interspersed between afferent terminals. Some neurons were di- 


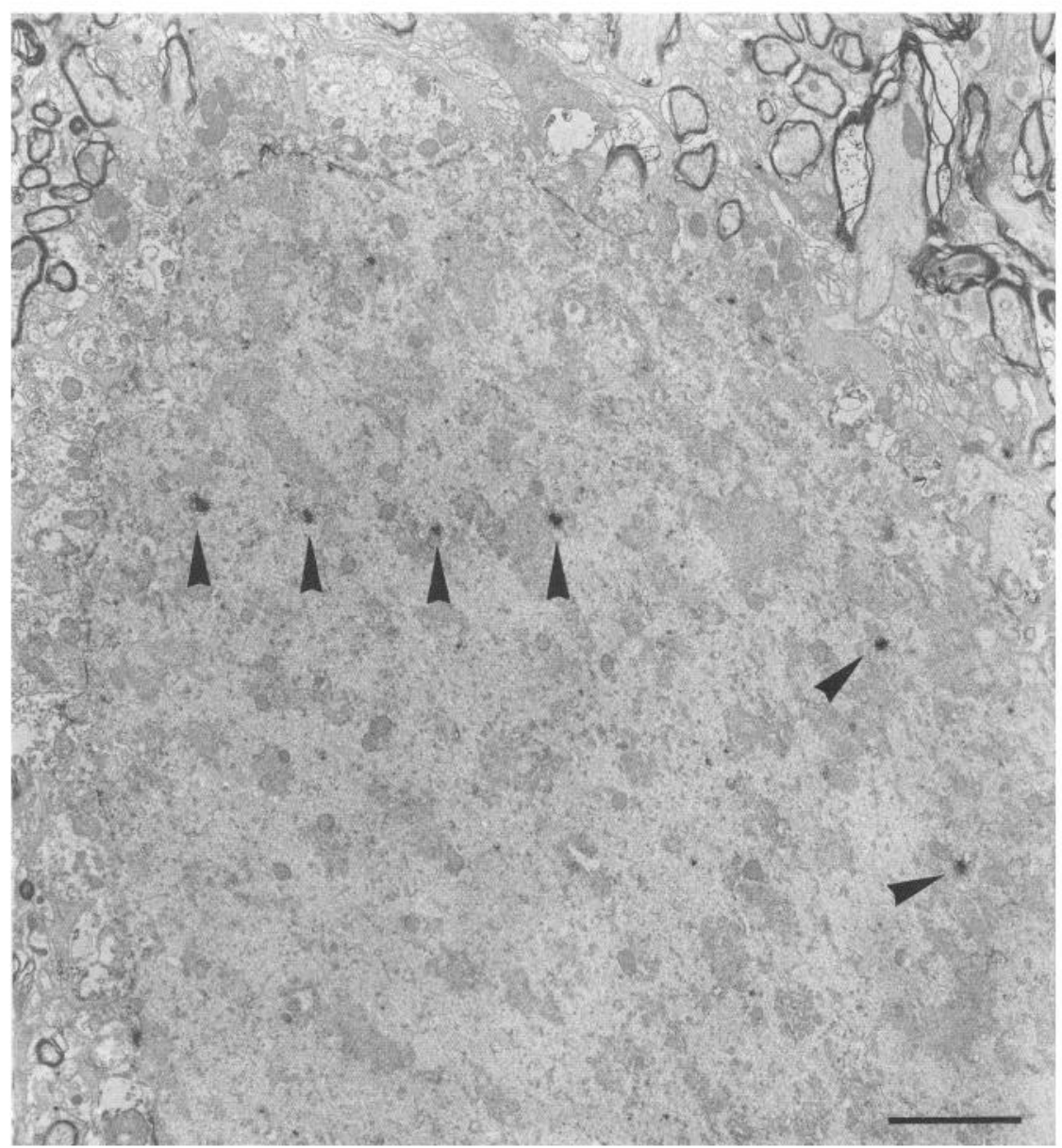

Figure 4. Evidence that the cytoplasmic dark reaction product (arrowheads) is located at a constant distance from the deafferented somatic M-cell membrane, $3 \mathrm{~d}$ after lesion. Scale bar, $4 \mu \mathrm{m}$. rectly in contact with electron-dense presynaptic endings, undergoing a degenerative process and facing immunolabeled postsynaptic membranes. The evolution in this transient cytoplasmic staining was identical to that of the M-cell.

\section{Extent of $93 \mathrm{kDa}$ labeling on postsynaptic membranes}

In order to establish if the length of the synaptic labeling was modified after lesions, the extent of the corresponding immunoprecipitate was compared from data collected in six control and six operated animals. As indicated by the histograms (Fig. $\left.6 A_{1}, B_{1}, C_{1}\right)$, obtained from random EM sections of lesioned animals, the mean length of labeled specialized membranes was $0.452 \mu \mathrm{m}(\mathrm{SD}=0.149 \mu \mathrm{m} ; n=75)$ on the cap dendrites, 0.761 $\mu \mathrm{m}(\mathrm{SD}=0.313 \mu \mathrm{m} ; n=74)$ on the ventral and lateral dendrites, and $0.653 \mu \mathrm{m}(\mathrm{SD}=0.265 \mu \mathrm{m} ; n=104)$ on the soma. In unoperated animals (Fig. $6 A_{2}, B_{2}, C_{2}$ ), the extent of the staining was about the same. More specifically, it averaged $0.447 \mu \mathrm{m}$ $(\mathrm{SD}=0.137 \mu \mathrm{m} ; n=62), 0.728 \mu \mathrm{m}(\mathrm{SD}=0.229 \mu \mathrm{m} ; n=130)$, and $0.656 \mu \mathrm{m}(\mathrm{SD}=0.290 \mu \mathrm{m} ; n=182)$ at the corresponding regions of the M-cell.

In contrast, the length of patches linked to degenerating somatic terminals was reduced to $0.504 \mu \mathrm{m}(\mathrm{SD}=0.157 \mu \mathrm{m} ; n$ $=25$ ) (Fig. $6 D$ ), that is, $77 \%$ that of the control. These data were obtained from stained postsynaptic densities in apposition to electron-dense endings still attached to the M-cell, one of which is shown in Figure $6 E$.

\section{Block of the GlyR complex by strychnine}

Swimming behavior of animals injected with strychnine was severely affected. At approximately $3 \mathrm{~min}$ after the first injection, the fish was stationary in a straight posture. The startle response did not habituate and 10 responses in series could be elicited at brief intervals by taps on the aquarium. After the second injection, the animals were lying on one side, on the bottom of the aquarium. At this stage, the stimulus triggered a strong contraction and a tremor of the muscles, but the animals were unable to swim.

\section{Block of synaptic responses by strychnine}

Intracellular recordings demonstrated that chronic injections of strychnine significantly impeded the $\mathrm{M}$-cell responses to activation of the recurrent collateral network that otherwise remained essentially unaltered. The experimental design (Fig. 7A) and the basic principles used to reach this conclusion were as follows.

First, after ortho- or antidromic firing of the M-cell, the presynaptic volleys in the terminals of collateral interneurons appear, in the axon cap, as a positive potential (Fig. $7 B_{l}$ ), the socalled extrinsic hyperpolarizing potential or EHP (Furukawa and Furshpan, 1963). In normal conditions, this volley evokes the glycine-mediated postsynaptic inhibition of the M-cell (referenced in Faber and Korn, 1982) and both disappear at stim- 
Figure 5. Partially denervated reticular neuron, at early $(3 \mathrm{~d})$ postoperative intervals: antigenicity to the $7 \mathrm{a} \mathrm{mAb}$ at normal synaptic contacts (arrows) and in the cytoplasm (triangles). Scale bar, $1 \mu \mathrm{m}$.

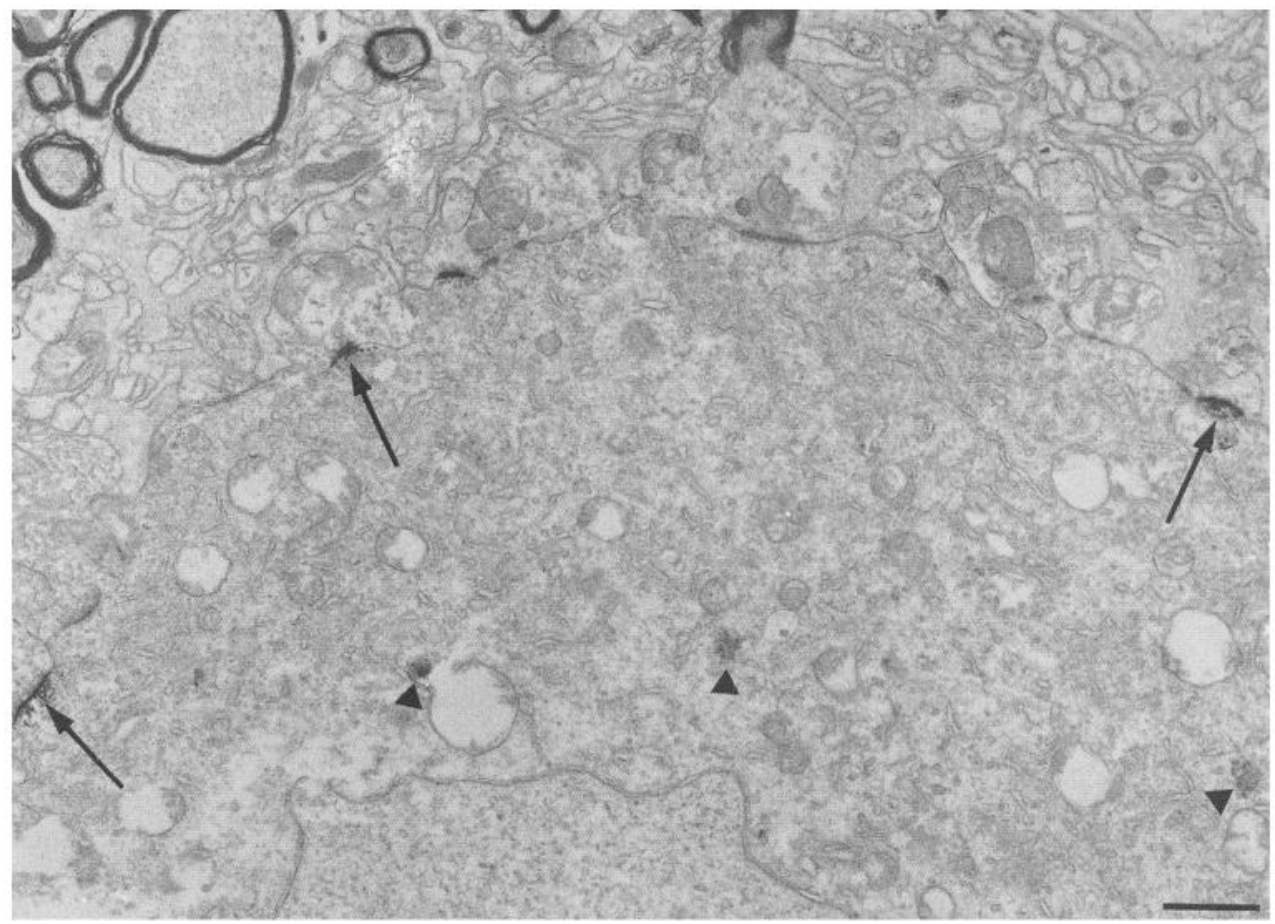

ulation rates of $>4 / \mathrm{sec}$ (Fig. $7 B_{2}$ ) due to a marked frequency sensitivity of the synapses intercalated along the collateral pathway (Faber and Korn, 1978). Second, the peak postsynaptic inhibitory conductance change, $G_{\mathrm{IPSP}}$ (or $G_{\text {coll. }}$ in the case of the inhibitory conductance underlying the collateral IPSP), can be determined by measuring its shunting effect on the height of a testing antidromic spike. Briefly, treating the M-cell membrane as having a resting conductance $G_{m}$, in parallel with the inhibitory channels and in series with the driving force for chloride, led to the expressions

$$
G(\operatorname{IPSP})=(r / 1-r) G_{m},
$$

with

$$
r=\left(V-V^{\prime}\right) / V,
$$

where $r$ is the fractional reduction of the spike, and $V$ and $V^{\prime}$ are the amplitudes of the control and test spikes, respectively (for derivations and justifications, see Faber and Korn, 1982). In practical terms, $V$ and $V^{\prime}$ can be assessed from the onset to the peak of the corresponding action potentials (Fig. $7 B_{3}, B_{4}$ ).

At all M-cells subjected to strychnine injections for $6 \mathrm{hr}(n=$ 3 ) or $3 \mathrm{~d}(n=6)$, the waveform and amplitude of the EHP were normal (Fig. $7 B_{l}$ ), indicating that the presynaptic volley reached the endings of the collateral neurons and that, as expected, it vanished during high-frequency stimulation rates (Fig. $7 B_{2}$ ). In contrast, and although the antidromic spike evoked by threshold spinal stimulation was normal (Fig. $7 B_{2}$ ), the collateral IPSP and its underlying conductance change were blocked by the drug, as shown by (1) the absence of $\mathrm{Cl}^{-}$-dependent voltage change after firing of the $\mathrm{M}$-cell, in recordings obtained with $\mathrm{KCl}$ electrodes (not shown), and (2) estimates of the parameter $r$, which was almost identical in a given cell, at slow (Fig. $7 B_{4}$ ) and at high (Fig. $7 B_{5}$ ) frequencies of antidromic stimulations, that is, when the reduction of the test height spike could be attributed to refractoriness alone. Also, when the strength of the spinal stimulus was increased, the test spike could summate with added EPSPs (Fig. $7 B_{6}$ ), a situation never encountered in the case of composite excitatory and inhibitory responses (Korn and Faber, 1975).

Pooled ( $n=9)$ mean values of $r$ in absence or in presence of collateral input were almost identical, $0.13 \pm 0.07$ ( \pm SD; range, $0.03-0.23)$ and $0.15 \pm 0.06( \pm \mathrm{SD}$; range, $0.05-0.24)$, respectively; the latter value indicates considerably less reduction in the test spike amplitude, at the peak of the anticipated collateral IPSP, than the $50-70 \%$ in normal conditions, as shown, for comparison, in Figure $7 C_{l}, C_{2}$ (see also Fukami et al., 1965; Korn and Faber, 1976).

\section{Morphological observations}

The distribution of the $\alpha$-subunit of the GlyR was examined with CSLM, $2 \mathrm{~d}(n=2$ fish) or $3 \mathrm{~d}(n=6)$ after the beginning of strychnine treatment. The immunoreactivity pattern of the surface receptors (Fig. $8 A_{1}$ ) did not differ from that of control $(n=10)$ animals (Fig. $8 B_{i}$; see also Triller et al., 1990). Fluo-

Figure 6. Morphometric data relative to the extent of the 93kd-IR on M-cell postsynaptic membrane, 3-5 d after surgery. $A-C$, Histograms of the length of the patches of $93 \mathrm{kDa}$ polypeptide that were apposed to the indicated regions of the M-cell in operated (left) and in control (right) animals with corresponding means $(m)$, SDs, and sample sizes (the first parameter was not significantly modified, as indicated by Student's $t$ tests). $D$. Frequency distribution of the $93 \mathrm{kd}-\mathrm{IR}$ size at synaptic contacts of degenerating endings in the somatic region. $E$, Electron micrograph showing a dark terminal bouton still in contact with the postsynaptic cell. Distance between bars, $0.45 \mu \mathrm{m}$. 
LENGTH OF 93 KD-IR APPOSED TO INTACT TERMINALS

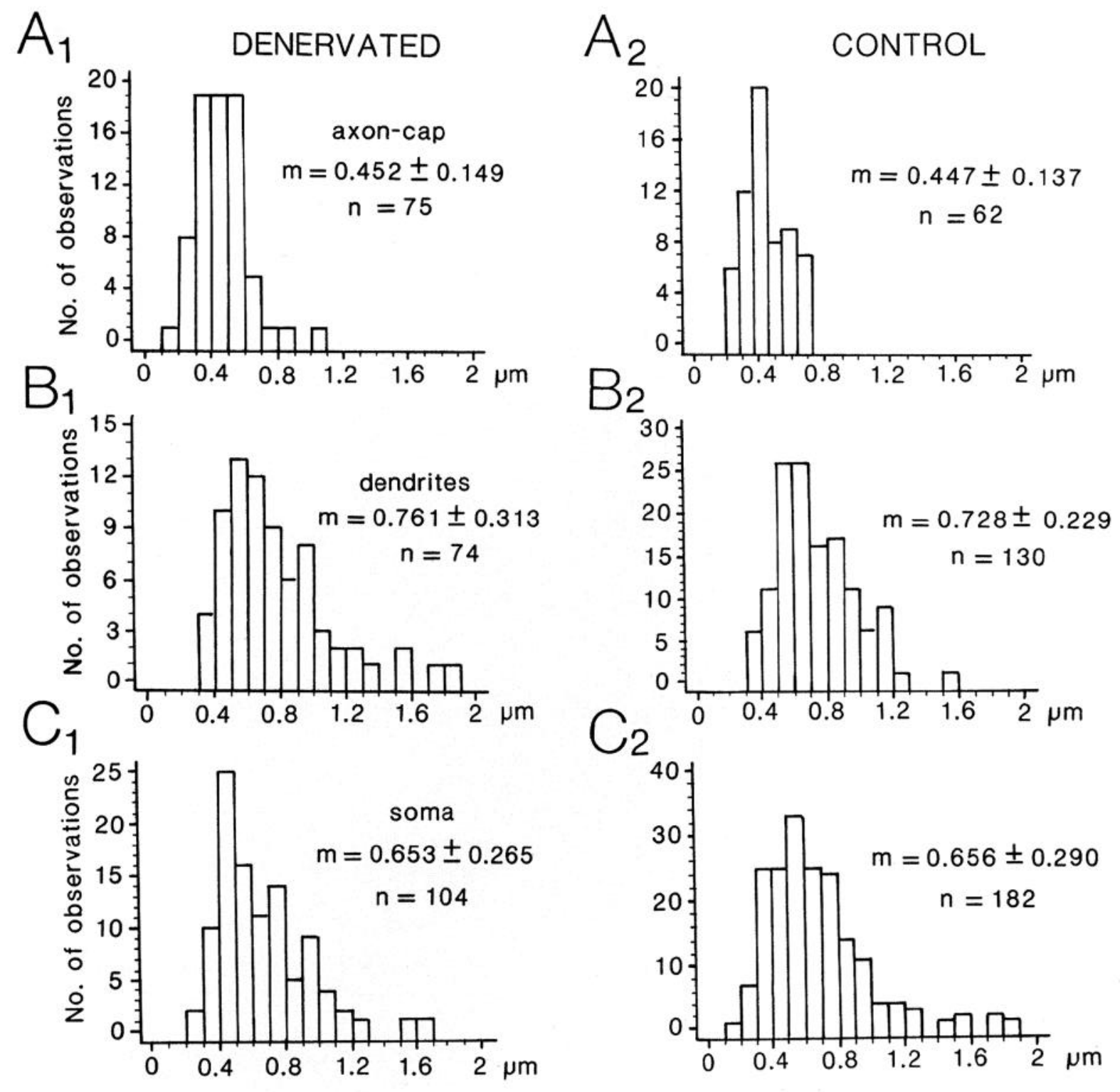

LENGTH OF 93 KD-IR APPOSED TO DEGENERATING TERMINALS
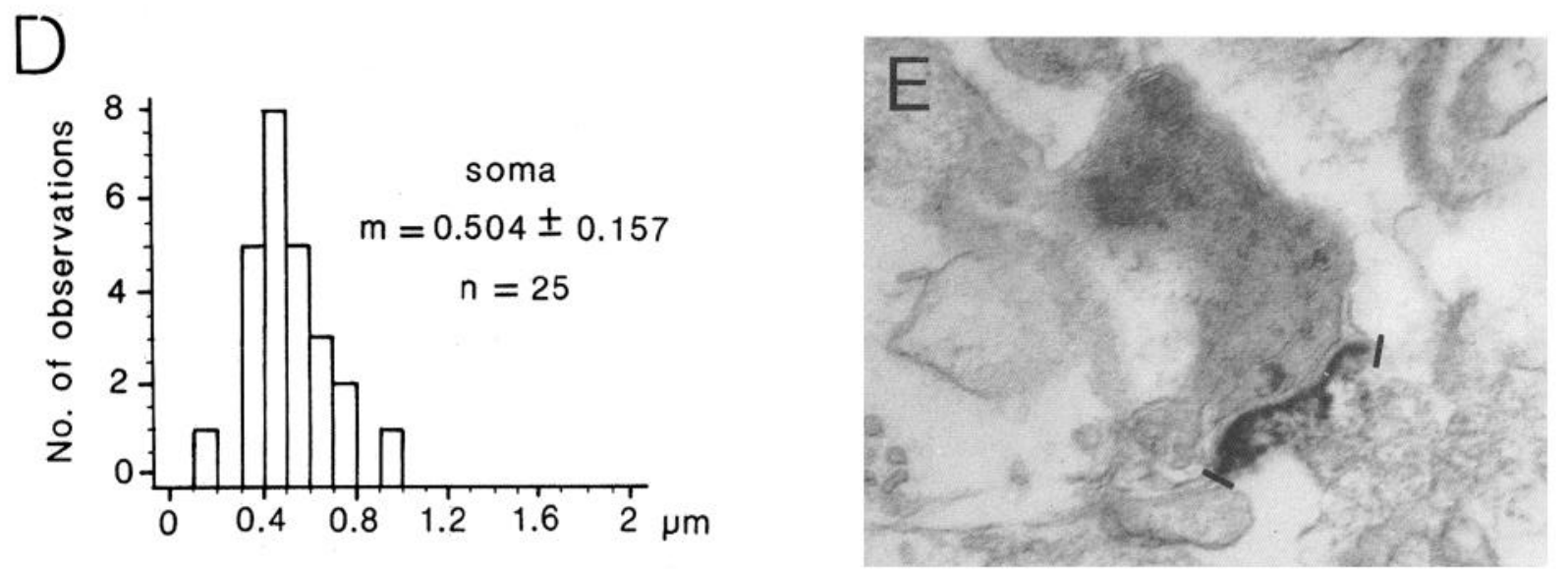

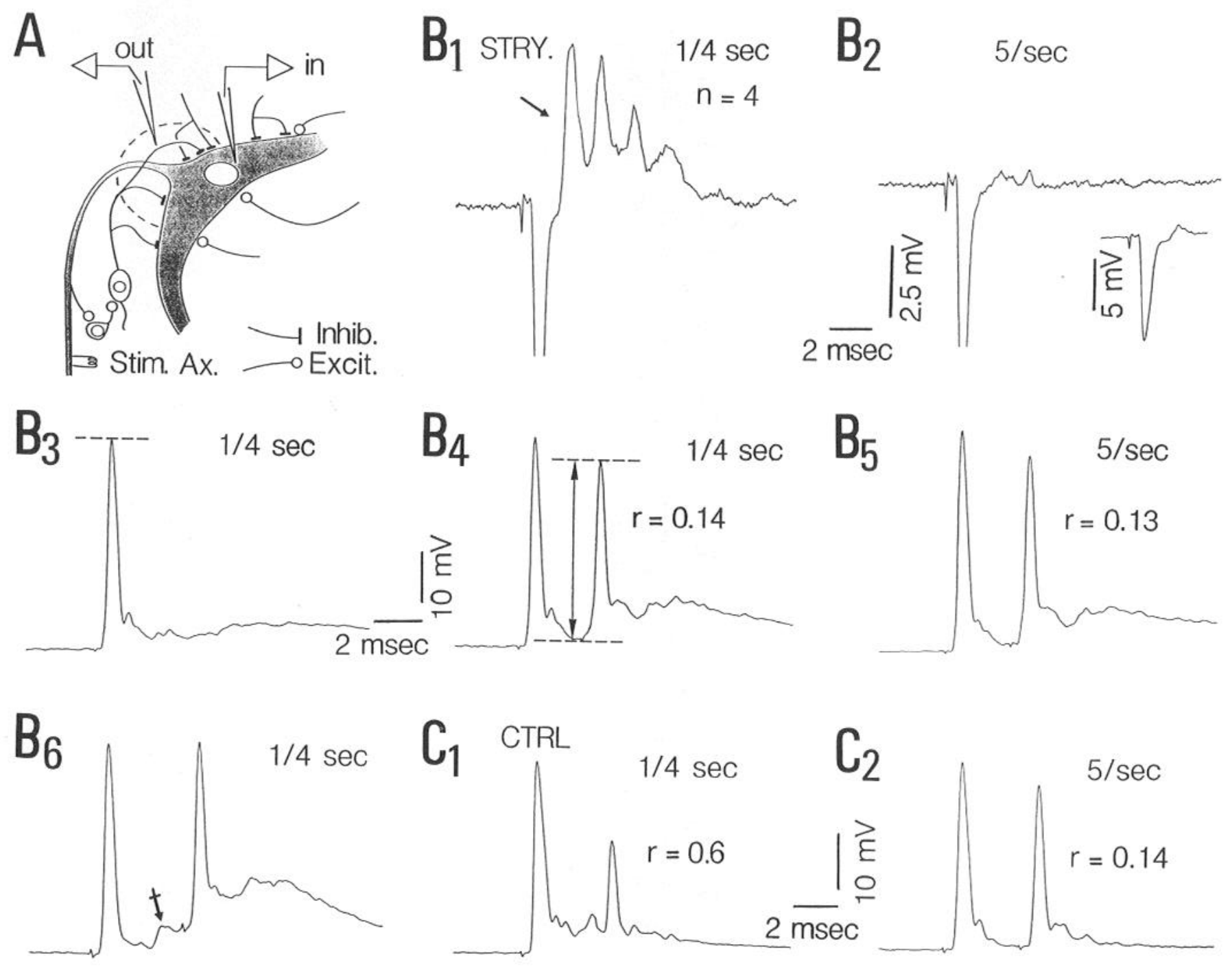

Figure 7. Electrophysiological analysis of strychnine effects on glycinergic transmission. A, Diagram of the experimental arrangement and the synaptic relations investigated, representing one class of interneurons, the collateral neurons, which mediate feedback inhibition of the M-cell (shaded area). Responses were monitored inside (in) or outside (out) the neuron, that is, in the axon cap (broken line), which was located on the basis of its characteristic responses to antidromic activation of the M-axon (Stim. Ax.). B, Results obtained after 3 d of chronic injection of strychnine. $B_{1}$ and $B_{2}$, Extracellular recordings of the M-cell spike (truncated, except in inset in $B_{2}$ ) followed by a typical presynaptic volley ( $B_{1}$, arrow), which disappeared $\left(B_{2}\right)$ at increased stimulation rates. $B_{3}-B_{6}$, Intracellular responses to single $\left(B_{3}\right)$ and paired $\left(B_{4}-B_{6}\right)$ antidromic stimulations at the indicated frequencies. Note that the fractional reduction of the second spike height, $r$ (see text) was nearly the same, whether the inhibitory network was activated $\left(B_{4}\right)$ or not $\left(B_{5}\right)$, indicating in both cases a lack of inhibitory response of the M-cell. With stronger stimulus intensities, the test spike did summate with evoked EPSPs $\left(B_{6}\right.$, crossed arrow). $C$, Same protocol as above, in an untreated (control) preparation, with indicated modifications of $r$ due to the collateral IPSP $\left(C_{1}\right)$ or to refractoriness alone $\left(C_{2}\right)$. Each trace in $B$ and $C$ is the average of four sweeps; recordings were obtained with $\mathrm{K}$-acetate-filled electrodes.

rescent clusters separated by unlabeled membrane patches were present in the entire M-cell plasmalemma. The high-resolution CSLM pictures allowed us to demonstrate that the size of each individually labeled microdomain remained unchanged. As illustrated in Figure $8 A_{2}$ and $B_{2}$, the mean surface area of somatic clusters was $0.53 \mu \mathrm{m}^{2}\left(\mathrm{SD}=0.41 \mu \mathrm{m}^{2} ; n=516\right)$ in strychnineinjected animals and $0.51 \mu \mathrm{m}^{2}\left(\mathrm{SD}=0.43 \mu \mathrm{m}^{2} ; n=970\right)$ in controls. These means were not significantly different $(p<0.05$, Student's $t$ test).

At the ultrastructural level, the localization of the $93 \mathrm{kDa}$ protein at synaptic contacts persisted the first $(n=1)$, the second $(n=2)$, and the third $(n=4)$ day of strychnine application (Fig. $8 C)$. The overall shape and the number $(39.3 \pm 1.71 \% ; n=4)$ of labeled synapses were identical to those of control prepara- tions (see Fig. 2A). Furthermore, the average diameter of the stained somatic contacts (mean $\pm \mathrm{SD}=0.639 \pm 0.232 \mu \mathrm{m} ; n$ $=105$ ) remained unchanged. In contrast to the denervation effect of the distribution on the $93 \mathrm{kDa}$ peripheral protein, intracellular antigenicity was absent in strychnine-treated M-cells. Finally, the distribution of the GlyR complex on reticular neurons was comparable to that in the M-cell.

\section{Discussion}

The major findings of this study, summarized in Table 1, were the following: (1) the short persistence of the postsynaptic 93 $\mathrm{kDa}$ protein at degenerating terminals and its transient appearance as clusters in the cytoplasm of the deafferented neurons, and (2) the absence of significant modifications of the GlyR and 

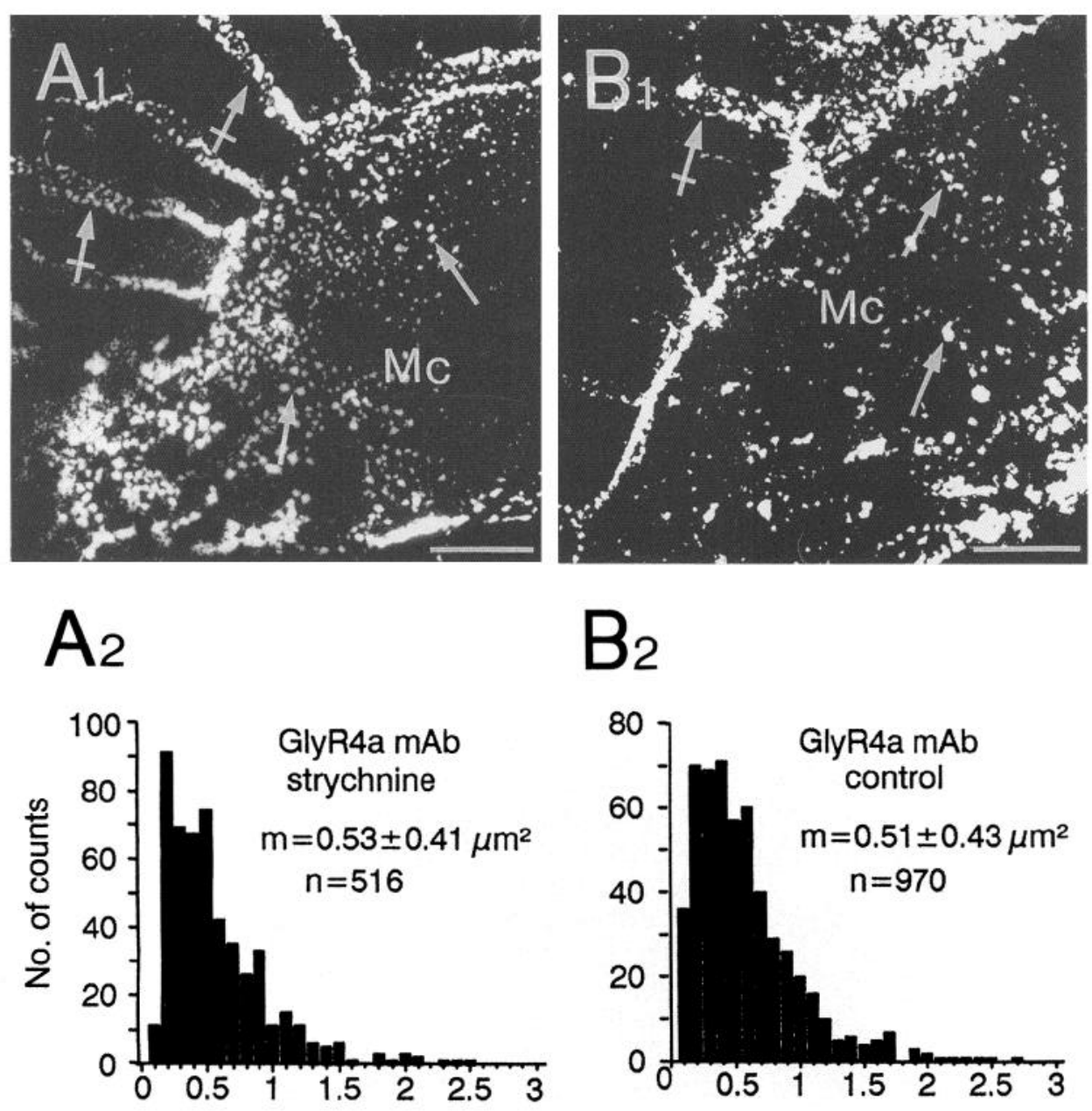

Surface area , $\mu \mathrm{m}^{2}$

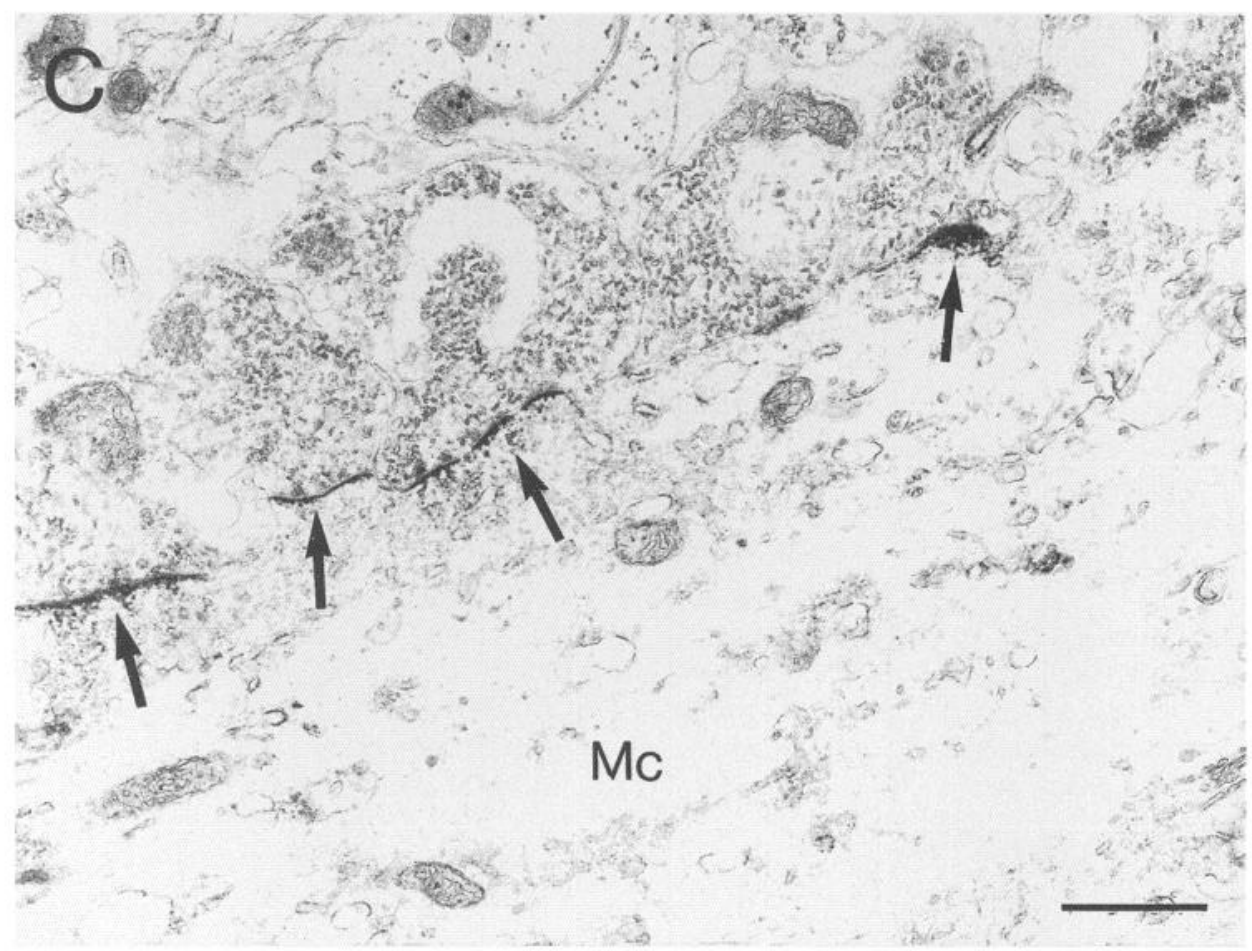

Figure 8. Unaltered cellular distribution of the GlyR complex on the M-cell, after chronic application of strychnine. $A$ and $B$, Effect of blockade of glycinergic transmission on the 48 kDa polypeptide. $A_{l}$ and $B_{l}$, Confocal fluorescent images of the $\alpha$-subunit on the soma (arrows) or on dendrites (crossed arrows), in treated $\left(A_{l}\right)$ and in control $\left(B_{1}\right)$ animals. $A_{2}$ and $B_{2}$, Frequency histograms of the surface areas of stained clusters obtained from the M-cell somatic region. Note that the means were not significantly different, as confirmed by a Student's $t$ test. $C$, Electron micrograph of somatic synaptic contacts (arrows) stained by the $7 \mathrm{a} \mathrm{mAb}$, with normal expression of the $93 \mathrm{kDa}$ protein. Note the absence of immunoprecipitate in the cytoplasm. $M c$, M-cell soma. Scale bars: $A_{l}$ and $B_{l}$, $6 \mu \mathrm{m} ; C, 725 \mathrm{~nm}$. 
of the $93 \mathrm{kDa}$ protein distribution after chronic block of synaptic transmission. Thus, our data suggest that factors, other than glycine, associated with the afferent nerve endings control the expression of these synaptic molecules.

\section{Glycinergic nature of the degenerating endings}

Different types of degenerative effects may coexist, such as those described in the axotomized M-cell, where terminal profiles display reactive deafferentation, but with no signs of degeneration (Wood and Faber, 1986). However, immunolabeling of the $93 \mathrm{kDa}$ protein requires a fixative containing a lower concentration of glutaraldehyde $(0.1 \%)$ than the $2.5 \%$ used by those authors. In order to avoid dubious interpretations of our data, we considered as degenerated fibers only those containing a dark electron-dense material.

The unilateral destruction of the vestibular nuclei caused the degeneration of no more than $10 \%$ of the terminal boutons on the soma of the M-cell. All the morphological criteria used to classify the afferents of the M-cell (Nakajima, 1974) could not be applied to these altered terminals; yet, their location on the M-cell already suggested that they belonged to UCEs in the axon cap, and SVBs when in contact with the soma, outsidc this region. Excitatory second-order vestibular neurons that cross the midline have been reported in other species (Graf and Ezure, 1986), but excitatory endings, containing gap junctions and identified as "club endings" (Nakajima, 1974), were never observed on the contralateral deafferented M-cell. Furthermore, the degenerating fibers were found in regions where the $93 \mathrm{kDa}$ polypeptide is expressed, and where activation of the crossed vestibular pathway produces a strong chloride-dependent inhibition that is mediated by glycine (Korn and Faber, 1976; Triller and Korn, 1981; Faber and Korn, 1982). However, electrolytic lesions could have caused also retrogade damage to contralateral neurons, some branches of which innervate the $\mathrm{M}$-cells. The influence of terminals other than glycinergic ones on the distribution of the $93 \mathrm{kDa}$ polypeptide during the early stage after lesion is unlikely, although heterologous regulation of neurotransmitter receptors has been reported in the CNS. In the rat brain, serotonergic deprivation results in an increase of $\alpha$-adrenergic receptors (Rappaport et al., 1985), and non-dopaminergic fibers modulate a $D_{1}$ receptor denervation supersensitivity (Hervé et al., 1989).

\section{Fate of postsynaptic sites and of synaptic $93 \mathrm{kd}-\mathrm{IR}$}

The 93kd-IR facing dark degenerating terminals remained behind the apposed synaptic contacts. Its average length was only slightly diminished compared with the control animals, $3 \mathrm{~d}$ after disruption of the crossed inhibitory input. We never observed changes in the density and/or small fragmentations of the synaptic $93 \mathrm{kDa}$ clusters, although low quantities of this polypeptide at extrasynaptic loci may have remained undetected with our immunohistochemical technique.

A persistence of postsynaptic specializations has been reported after primary deafferentation in the ventral cochlcar nucleus of the rat (Gentschev and Sotelo, 1973), and after sectioning the preganglionic fibers in frog sympathetic ganglia (Sotelo, 1968). In our material, unoccupied stained postsynaptic densities that persisted only during the early phase of the degenerative process seem to have shorter life spans. Reoccupation of vacant postsynaptic sites by a sliding process from adjacent intact terminals (Gentschev and Sotelo, 1973) was never observed at early or late postoperative intervals. Thus, it is unlikely that reinervation of preexisting labeled membrane patches due to collateral sprouting of proximal axons takes place during the first 2 weeks following our lesions, which is the longest time period covered by this study.

\section{Comparison with the nicotinic receptor-associated $43 \mathrm{kDa}$ protein}

Several lines of evidence suggest that membrane proteins are involved in the anchoring and/or the maintenance of the receptor clusters (Bloch and Froehner, 1987; Schmitt et al., 1987; Kordeli et al., 1989) via interactions with the cytoskeleton. No conclusive data are yet available on the role of innervation on the distribution of the $43 \mathrm{kDa}$ protein. Accumulation and clustering of the $43 \mathrm{kDa}$ protein can occur in the absence of afferent nerve (Peng and Froehner, 1985; Bloch and Froehner, 1987; Kordeli et al., 1989), and a diffuse cytoplasmic form has been detected in developing electrocytes (Kordeli et al., 1989). Other studies have shown that denervation causes a threefold increase in the amount of the mRNA for the $43 \mathrm{kDa}$ protein in a leg muscle of the adult mouse (Frail et al., 1989).

\section{Possible function of the cytoplasmic $93 \mathrm{kDa}$ polypeptide}

The transient appearance of the 93kd-IR in the cytoplasm of the denervated cells may result from (1) a decrease in the rate of its transport to the plasma membrane, (2) an increased rate of its synthesis, or (3) an alteration in any postranslational modification that would affect the expression of the epitope. It may also be the consequence of the $93 \mathrm{kDa}$ protein recycling from the deafferented synapses. A number of other receptors such as those of NGF or epidermal growth factor are known to be recycled with their ligands (for review, see Greene and Shooter, 1980; Goldstein et al., 1985). However, internalization seems unlikely in our experiments, since the only labeled vesicles observed occasionally were close to the Golgi apparatus, that is, far from the somatic membrane.

A different mechanism for internalization of the components of the postsynaptic site has been reported in the ventral cochlear nucleus of the rat (Gentschev and Sotelo, 1973), where entire free postsynaptic sites were eliminated by engulfment into the cytoplasm. In the M-cell, unstained internalized postsynaptic densities were never observed. Furthermore, in the labeled cytoplasmic cluster of the $93 \mathrm{kDa}$ protein, membrane remnants were never visualized and intracellular clusters were detected in the principal dendrites where degenerating profiles were not found.

The pattern of the cytoplasmic staining of the $93 \mathrm{kDa}$ protein described in this work completely differs from that of the nicotinic receptor in the chicken ciliary ganglia (Jacob et al., 1986; Jacob and Berg, 1987) and of the GABA receptor in the rat cerebellum (Somogyi et al., 1989). In these studies, the intracellular immunoreactivity was only associated with membranebound organelles like the endoplasmic reticulum or the Golgi apparatus, or the nuclear envelope. This difference was expected since transmembrane subunits, like those of glycine, $\mathrm{ACh}$, and GABA receptors, are thought to be synthesized and modified in the rough endoplasmic reticulum and sorted out in the Golgi apparatus (Rothman and Fine, 1980). Conversely, the $93 \mathrm{kDa}$ polypeptide is a nonglycosylated peripheral membrane protein and should not follow the same biosynthetic or regulatory pathway; it is most probably synthesized by free polyribosomes. The staining of the Golgi by the $7 \mathrm{a} \mathrm{mAb}$ might result from an early association at this level of the cytoplasmic $93 \mathrm{kDa}$ polypeptide 
to the glycine receptor transmembrane subunits, before their translocation and their subsequent insertion into the plasma membrane. It is also possible that proximal vesicles and Golgi membranes, or even ribosomes, are stained, due to absorption of translocated DAB precipitate during the enzymatic immunoreaction.

Since intracellular clusters of 93kd-IR were not apparent in the axon hillock or the $\mathrm{M}$-cell axon, passive diffusion seems unlikely to account for their transport in the dendrites. Rather, their location at a fixed distance from the plasma membrane (Fig. 4) suggests the involvement of the cytoskeleton. An example of a similar mechanism of a nonvesicular transport of molecules by the cytoskeleton was reported in cultured hippocampal neurons where newly synthetized mRNA is transported to the dendrites (Davis et al., 1987). Such an active transport may contribute to selectively direct and segregate proteins at specialized regions, such as surface microdomains of central neurons. A subplasmalemmal synaptic molecule, like the 93 $\mathrm{kDa}$ polypeptide, should be only localized at restricted areas of the plasma membrane, associated with the appropriate receptor, and functionally match with its corresponding presynaptic element. Along this line, in multinucleated muscle fibers from mature animals, $\mathrm{ACh}$ receptors are preferentially transcribed and synthetized by a few nuclei at synaptic areas (Merlie and Sanes, 1985; Fontaine et al., 1988).

\section{Chronic block of synaptic responses}

It has long been shown that strychnine blocks the collateral IPSP (Furukawa et al., 1963), a property extensively used to demonstrate that, although GABA receptors are present on the M-cell (Diamond and Roper, 1973; Diamond et al., 1973; Faber and Korn, 1980), glycine is the major transmitter operant at the somatic level (Mazliah and Werman, 1974; Faber and Korn, 1982), including at synapses issued by the commissural interneurons (Faber and Korn, 1988). Also, despite suggestions that in other systems, strychnine may affect responses mediated by GABA (Davidoff et al., 1969), the latter are not changed in this neuron by doses of the drug that block the collateral IPSP (Diamond et al., 1973).

Recovery of synaptic potentials from a block by strychnine is exceptional during acute experiments and was only observed when low amounts of the antagonist were injected iontophoretically in the axon cap to verify that the background synaptic noise is inhibitory in the M-cell (Korn and Faber, 1990), yet prolonged exposure of neurons to strychnine has not been attempted in vivo for behavioral and/or physiological studies of its long-term effects that in the present study remained confined to the GlyRs. Indeed, spike amplitudes $(30-50 \mathrm{mV})$ and resting potential $(75-80 \mathrm{mV}$ ) were as in normal M-cell somata (Faber and Korn, 1978). EPSPs unmasked by the relief of inhibition were also the same (Furukawa et al., 1963) as well as the refractoriness of test spikes during paired stimulations at closed intervals. Only $G_{m}$, the input conductance, was unusually elevated since it averaged $13.8 \pm 1.65 \mu \mathrm{S}( \pm \mathrm{SD} ; n=5$; range, $11-$ $15 \mu \mathrm{S}$ ), which is higher than the $6.08 \mu \mathrm{S}$ and $6.2 \mu \mathrm{S}$ in currentand voltage-clamp, respectively (Faber and Korn, 1982, 1988). This value returns to the lowest ranges of the early estimates of M-cell input resistances (Furshpan and Furukawa, 1962; Fukami et al., 1965). The resting M-cell's conductance is dominated by a voltage-dependent $\mathrm{K}^{+}$conductance (Faber and Korn, 1986), and a nonspecific effect of strychnine on the cell's membrane is the most likely explanation for this finding.
The effectiveness of the chronic block of synaptic transmission was ascertained using Equation 1 to estimate $G_{\text {coll. }}$. With parameters $r$ obtained at slow stimulation rates, the mean collateral conductance equaled $1.9 \pm 0.9 \mu \mathrm{S}(n=5)$, which is already $30 \%$ of that in control conditions (Faber and Korn, 1982; Korn and Faber, 1990). This estimate dropped to $0.4 \pm 0.35 \mu \mathrm{S}( \pm \mathrm{SD} ; n$ $=5$; range, $0-1.0 \mu \mathrm{S}$ ) when correcting $r$ for refractoriness. Previous recordings of pairs of neurons and quantal analysis support the notion that the effect of strychnine was postsynaptic, since in acute experiments, the drug reduced the quantal conductance with little influence on the presynaptic releasing parameters $n$ and $p$ (Faber and Korn, 1988). Whatever its origin, our data indicate that a larger fraction of glycinergic junctions was involved by prolonged applications of strychnine than after denervation.

\section{Absence of morphological effects of the "functional" denervation}

The specificity of strychnine's action on the glycinergic postsynaptic sites has been recognized (Young and Snyder, 1973, 1974; Faber and Korn, 1988), and its effects on other receptor systems occur at concentrations above its $k_{d}$ at the inhibitory GlyR by a factor of 100-50 × $10^{6}$ (Baron and Guth, 1987). Thus, although there is a GlyR less sensitive to strychnine in the spinal cord of cats (Ryall et al., 1972), in neonatal rats (Becker et al., 1988; Hoch et al., 1989), in primary cultures of fetal motoneurons (Hoch et al., 1989), and in medullary neurons (Lewis et al., 1989), it is unlikely that their presence accounts for the failure of the antagonist to reproduce the morphological effects of denervation, since the M-cell somatic IPSPs and inhibitory postsynaptic currents are completely abolished by low doses of strychnine (Faber and Korn, 1988). Furthermore, the staining of the GlyR $48 \mathrm{kDa}$ channel-forming polypeptide was not hampered by strychnine. This was probably due to the fact that the epitope of this immunoglobulin is located within the first 100 amino acids of the $48 \mathrm{kDa}$ chain and is different from the antagonist binding site (Schröder et al., 1991).

As for the neuronal nicotinic receptor, denervation of the cardiac ganglion neurons causes a decrease of the total number of the surface ACh receptors (Sargent and Pang, 1988) and that of the chick ciliary ganglion produces a decline in the number of intracellular receptors, leaving unaffected the postsynaptic ones (Jacob and Berg, 1987, 1988).

These data, and our results, contrast with those obtained at the neuromuscular junction or on the electrocytes, where denervation (Bourgeois et al., 1973, 1978a; Fambrough, 1974; Loring and Salpeter, 1980), as well as a postsynaptic blockade of the receptors by $d$-tubocurarine (Berg and Hall, 1975) or $\alpha$-bungarotoxin (Chang et al., 1975), and presynaptic inhibition by botulinum toxin (Chang et al., 1975; Bourgeois et al., 1978b) all caused the appearence of extrajunctional $\mathrm{ACh}$ receptors over the entire myofiber surface. These treatments were reported to accelerate the turnover of the junctional $\mathrm{ACh}$ receptors (Loring and Salpeter, 1980; Avila et al., 1989; Fumagalli et al., 1990). However, their number revealed after labeling with ${ }^{125} \mathrm{I}-\alpha$-bungarotoxin remained intact $18 \mathrm{~d}$ after denervation (Porter and Barnard, 1975). Several factors that interfere with the synthesis or clustering of $\mathrm{ACh}$ receptors have been recently identified, including the calcitonin gene-related peptide (Laufer and Changeux, 1987), or agrin, that is released from the presynaptic nerve ending (Godfrey et al., 1984; Nitkin et al., 1987) and whose staining intensity decreases after denervation (Reist et al., 1987). 
We observed that the denervated $93 \mathrm{kDa}-\mathrm{immunostained}$ synapses do not persist and a transient intracellular $93 \mathrm{kd}-\mathrm{IR}$ appears after denervation; these changes were absent after functional blockade of the glycinergic synaptic transmission. Furthermore, the distribution of the $\alpha$-subunit of the GlyR remained unaltered after strychnine treatment. This implies that the interruption of GlyR activation is not sufficient to trigger the redistribution of postsynaptic protein. Other types of interactions may be involved between the pre- and the postsynaptic cell. These could include the corelease of other molecules together with glycine or the structural contact of the intact afference with the postsynaptic element.

\section{References}

Altschuler RA, Betz H, Parakkal MH, Reeks AK, Wenthold RJ (1986) Identification of glycinergic synapses in the cochlear nucleus through immunocytochemical localization of the postsynaptic receptor. Brain Res 369:316-320.

Avila OL, Dracham DB, Pestronk A (1989) Neurotransmission regulates stability of acetylcholine receptors at the neuromuscular junction. J Neurosci 9:2902-2906.

Baron CE, Guth PS (1987) Uses and limitations of strychnine as a probe in neurotransmission. Trends Pharmacol Sci 8:204-206.

Becker C-M, Hoch W, Betz H (1988) Heterogeneity in rat spinal cord during postnatal development. EMBO J 7:3717-3726.

Becker C-M, Seitanidou T, Triller A (1991) Conservation of antigenic epitopes of the inhibitory glycine receptor in rodent and goldfish CNS. Mol Brain Res, submitted.

Berg DK, Hall ZW (1975) Increased extrajunctional acetylcholine sensitivity produced by chronic post-synaptic neuromuscular blockade. J Physiol (Lond) 244:659-676.

Betz H, Becker C-M (1988) The mammalian glycine receptor: biology and structure of a neuronal chloride channel protein. Neurochem Int 13:137-146.

Bloch RJ, Froehner SC (1987) The relationship of the postsynaptic $43 \mathrm{~K}$ protein to acetylcholine receptors in receptor clusters isolated from cultured rat myotubes. J Cell Biol 104:645-654.

Bourgeois J-P, Popot J-C, Ryter A, Changeux J-P (1973) Consequences of denervation on the distribution of the cholinergic (nicotinic) receptor sites from Electrophorus electricus revealed by high resolution autoradiography. Brain Res 62:557-563.

Bourgeois J-P, Popot J-C, Ryter A, Changeux J-P (1978a) Quantitative studies on the localization of the cholinergic receptor protein in the normal and denervated Electrophorus electricus. J Cell Biol 79:200216.

Bourgeois J-P, Betz H, Changeux J-P (1978b) Effets de la paralysie chronique de l'embryon de poulet par le flaxédil sur le développement de la jonction neuromusculaire. CR Acad Sci (Paris) 286D:773-776.

Bridgman PC, Carr C, Pedersen SE, Cohen JB (1987) Visualization of the cytoplasmic surface of Torpedo postsynaptic membrane by freeze-etch and immuno-electron microscopy. J Cell Biol 105:18261846.

Burden SJ, De Palma RL, Gottesman GS (1983) Cross-linking of proteins in acetylcholine receptor-rich membranes: association between the beta-subunit and the $43 \mathrm{Kd}$ subsynaptic protein. Cell 35 : $687-692$.

Carlsson K, Åslund N (1987) Confocal imaging for 3-D digital microscopy. Appl Optics 26:3232-3238.

Cartaud J, Sobel A, Rousselet A, Devaux PF, Changeux JP (1981) Consequences of alkaline treatment for the ultrastructure of the acetylcholine receptor-rich membranes from Torpedo marmorata electric organ. J Cell Biol 90:418-426.

Chang CC, Chuang ST, Huang MC (1975) Effects of chronic treatment with various neuromuscular blocking agents on the number and distribution of the acetylcholine receptors in the rat diaphragm. J Physiol (Lond) 250:161-173.

Davidoff RA, Aprison MH, Werman K (1969) The effects of strychnine on the inhibition of interneurons by glycine and gamma-aminobutyric acid. Int J Neuropharmacol 8:191-194.

Davis L, Banker GA, Steward O (1987) Selective dendritic transport of RNA in hippocampal neurons in culture. Nature 330:477-479.
Diamond J, Roper S (1973) Analysis of the Mauthner responses to iontophoretically delivered pulses of GABA, glycine and L-glutamate. J Physiol (Lond) 232:113-128.

Diamond J, Roper S, Yasargil G (1973) The membrane effects and sensitivity of strychnine, of neural inhibition of the Mauthner cell, and its inhibition by glycine and GABA. J Physiol (Lond) 232:87111.

Faber DS, Korn H (1973) A neuronal inhibition mediated electrically. Science 179:577-578.

Faber DS, Korn H (1978) Electrophysiology of the Mauthner cell: basic properties, synaptic mechanisms, and associated networks. In: Neurobiology of the Mauthner cell (Faber DS, Korn H, eds), pp 47131. New York: Raven.

Faber DS, Korn H (1980) Single-shot channel activation accounts for duration of inhibitory postsynaptic potentials in a central neuron. Science 208:612-615.

Faber DS, Korn H (1982) Transmission at a central inhibitory synapse. I. Magnitude of unitary postsynaptic conductance change and kinetics of channel activation. J Neurophysiol 48:654-678.

Faber DS, Korn H (1986) Instantaneous inward rectification in the Mauthner cell: a postsynaptic booster for excitatory inputs. Neuroscience 9:1037-1043.

Faber DS, Korn H (1988) Unitary conductance changes at teleost Mauthner cell glycinergic synapses. A voltage clamp and pharmacologic analysis. J Neurophysiol 60:1982-1999.

Fambrough DM (1974) Acetylcholine receptors. Revised estimates of extrajunctional receptor density in denervated rat diaphragm. J Gen Physiol 64:468-472.

Fambrough DM (1979) Control of acetylcholine receptors in skeletal muscle. Physiol Rev 59:165-227.

Fontaine B, Sassoon D, Buckingham M, Changeux J-P (1988) Detection of the nicotinic acetylcholine receptor alpha-subunit mRNA by in situ hybridization at neuromuscular junctions of 15-day-old chick striated muscles. EMBO J 7:603-609.

Frail DE, Musil LS, Buonanno A, Merlie JP (1989) Expression of RAPsyn (43K protein) and nicotinic acetylcholine receptor genes is not coordinately regulated in mouse muscle. Neuron 2:1077-1086.

Froehner SC, Gulbandsen V, Hyman C, Jeng AY, Neubig RR, Cohen JB (1981) Immunofluorescent localization at the mammalian neuromuscular junction of the $\mathrm{M}, 43000$ protein of Torpedo postsynaptic membranes. Proc Natl Acad Sci USA 78:5230-5234.

Froehner SC, Luetje CW, Scotland PB, Patrick J (1990) The postsynaptic $43 \mathrm{~K}$ protein clusters muscle nicotinic acetylcholine receptors in Xenopus oocytes. Neuron 5:403-410.

Fukami Y, Furukawa T, Asada Y (1965) Excitability changes of the Mauthner cell during collateral inhibition. J Gen Physiol 48:581-600.

Fumagalli G, Balbi S, Cangiano A, Lomo T (1990) Regulation of turnover and number of acetylcholine receptors at neuromuscular junctions. Neuron 4:563-569.

Furshpan EJ, Furukawa T (1962) Intracellular and extracellular responses of the several regions of the Mauthner cell of the goldfish. J Neurophysiol 25:732-771.

Furukawa T, Furshpan EJ (1963) Two inhibitory mechanisms in the Mauthner neurons of the goldfish. J Neurophysiol 26:140-176.

Furukawa T, Fukami Y, Asada Y (1963) Effects of strychnine and procaine on the collateral inhibition of the Mauthner cell of the goldfish. Jpn J Physiol 14:386-399.

Gentschev T, Sotelo C (1973) Degenerative patterns in the ventral cochlear nucleus of the rat after primary deafferentation. An ultrastructural study. Brain Res 62:37-60.

Godfrey EW, Nitkin RM, Wallace GB, Rubin LL, McMahan UJ (1984) Components of Torpedo electric organ and muscle that cause aggregation of acetylcholine receptors on cultured muscle cells. J Cell Biol 99:615-627.

Goldstein JL, Brown MS, Anderson RGW, Russell DW, Schreider WJ (1985) Receptor mediated endocytosis: concepts emerging from the LDL receptor system. Annu Rev Cell Biol 1:1-39.

Graf W, Ezure K (1986) Morphology of vertical canal second order vestibular neurons in the cat. Exp Brain Res 63:35-48.

Greene LA, Shooter EM (1980) The nerve growth factor: biochemistry synthesis, and mechanism of action. Annu Rev Neurosci 3:353-402.

Hervě D, Trovero F, Blanc G, Thierry A-M, Glowinski J, Tassin J-P (1989) Nondopaminergic prefrontocortical efferent fibers modulate $D_{1}$ receptor denervation supersensitivity in specific regions of the rat striatum. J Neurosci 9:3699-3708.

Hoch W, Betz H, Becker C-M (1989) Primary cultures of mouse spinal 
cord expresses the neonatal isoform of the inhibitory glycine receptor. Neuron 3:339-348.

Hsu SM, Raine L, Fanger H (1981) Use of avidin-biotin-peroxidase complex $(\mathrm{ABC})$ in immunoperoxidase techniques: a comparison between $\mathrm{ABC}$ and unlabelled antibody (PAP) procedures. J Histochem Cytochem 29:577-580.

Jacob MH, Berg DK (1987) Effects of preganglionic denervation and postganglionic axotomy on acetylcholine receptors in the chick ciliary ganglion. J Cell Biol 105:1847-1854.

Jacob MH, Berg DK (1988) The distribution of acetylcholine receptors in chick ciliary ganglion neurons following disruption of ganglionic connections. J Neurosci 8:3838-3849.

Jacob MH, Lindstrom JM, Berg DK (1986) Surface and intracellular distribution of a putative neuronal acetylcholine receptor. J Cell Biol 103:205-214.

Kordeli E, Cartaud J, Nghiem H-O, Devillers-Thiery A, Changeux J-P (1989) Asynchronous assembly of the acetylcholine receptor and of the $43 \mathrm{Kd}_{1}$ protein in the postsynaptic membrane of developing Torpedo marmorata electrocyte. J Cell Biol 108:127-139.

Korn H, Faber DS (1975) Inputs from the posterior lateral line nerves upon the goldfish Mauthner cell. I. Properties and synaptic localization of the excitatory component. Brain Res 96:1166-1169.

Korn H, Faber DS (1976) Vertebrate central neurons system: same neurons mediate both electrical and chemical inhibitions. Science 194:1166-1169.

Korn H, Faber DS (1990) Transmission at a central inhibitory synapse. IV. Quantal structure of synaptic noise. J Neurophysiol 63:198-222.

Korn H, Faber DS, Triller A (1990) Convergence of morphological, physiological and immunocytochemical techniques for the study of single Mauthner cells. In: Handbook of chemical neuroanatomy, Vol 8, Analysis of ncuronal microcircuits and synaptic interactions (Björklund A, Hökfelt T, Wounterlood FG, Van den Pol AN, eds). Amsterdam: Elsevier.

Laufer R, Changeux J-P (1987) Calcitonin gene-related peptide elevates cyclic-AMP levels in chick skeletal muscle: possible neurotrophic role for a coexisting neuronal messenger. EMBO J 6:901-906.

Lewis CA, Ahmed Z, Faber DS (1989) Characteristics of glycineactivated conductances in cultured medullary neurons from embryonic rat. Neurosci Lett 96:185-190.

Loring RH, Salpeter MM (1980) Denervation increases turnover rate of junctional acetylcholine receptors. Proc Natl Acad Sci USA 77: 2293-2297.

Mazliah Y, Werman R (1974) The actions of glycine and GABA compared on the same cells on vertebrates. Isr J Med Sci 10:566.

Mcrlic JP, Sanes JR (1985) Concentration of acctylcholinc reccptor mRNA in synaptic regions of adult muscle fibres. Nature 317:66-68.

Moore RY (1981) Methods for selective restricted lesion placement in the central nervous system. In: Neuroanatomical tract-tracing methods (Heimer L, Robards MJ, eds), pp 55-89. New York: Plenum.

Nakajima $Y$ (1974) Fine structure of the synaptic endings on the Mauthner cell of the goldfish. J Comp Neurol 156:375-402.

Nitkin RM, Smith MA, Magill C, Fallon JR, Yao Y-MM, Wallace BG, McMahan UJ (1987) Identification of agrin, a synaptic organizing protein from Torpedo electric organ. J Cell Biol 105:2471-2478.

Peng HB, Froehner SC (1985) Association of the postsynaptic 43k protein with newly formed acetylcholine receptor clusters in cultured muscle cells. J Cell Biol 100:1698-1705.

Pfeiffer F, Simler R, Grenningloh G, Betz H (1984) Monoclonal antibodics and peptide mapping revcal structural similaritics betwecn the subunits of the glycine receptor on the rat spinal cord. Proc Natl Acad Sci USA 81:7224-7227.

Phillips WD, Kopta C, Blount P, Gardner PD, Steinback JH, Merlie JP (1991) Ach receptor-rich membrane domains organized in fibroblasts by recombinant 43 kilodalton protein. Science 251:568570.

Porter CW, Barnard EA (1975) Distribution and density of cholinergic receptors at the motor endplates of a denervated mouse muscle. Exp Neurol 48:542-556.

Rappaport A, Sturtz F, Guicheney P (1985) Regulation of central alpha-adrenoceptors by serotoninergic denervation. Brain Res 344 : 158-161.

Reist NE, Magill C, McMahan UJ (1987) Agrin-like molecules at synaptic sites in normal, denervated and damaged skeletal muscles. J Cell Biol 105:2457-2469.

Rothman JE, Fine RE (1980) Coated vesicles transport newly syn- thesized membrane glycoproteins from endoplasmic reticulum to plasma membrane in two successive stages. Proc Natl Acad Sci USA 77:780-784.

Rousselet A, Cartaud J, Devaux PF, Changeux JP (1982) The rotational diffusion of acetylcholine receptor in Torpedo marmorata membrane fragments studicd with a spin-labeled A-toxin: importance of the 43000 protein(s). EMBO J 1:439-445.

Ryall RW, Piercey MF, Polosa C (1972) Strychnine-resistant mutual inhibition of Renshaw cells. Brain Res 41:119-129.

Sargent PB, Pang DZ (1988) Denervation alters the size, number and distribution of clusters of acetylcholine receptor-like molecules on frog cardiac ganglion neurons. Neuron 1:877-886.

Schmitt B, Knaus P, Becker CM, Betz H (1987) The M, 93000 polypeptide of the postsynaptic glycine receptor complex is a peripheral membrane protein. Biochemistry 26:805-811.

Schröder S, Hoch W, Becker C-M, Grenningloh G, Betz H (1991) Mapping of antigenic epitopes on the $A_{1}$ subunit of the inhibitory glycine receptor. Biochemistry, in press.

Schuetze SM, Role LW (1987) Developmental regulation of the nicotinic acetylcholine receptors. Annu Rev Ncurosci 10:403-457.

Sealock R, Wray BE, Froehner SC (1984) Ultrastructural localization of the $\mathbf{M}_{r} 43,000$ protein and the acetylcholine receptor in Torpedo postsynaptic membranes using monoclonal antibodies. J Cell Biol 98: 2239-2244.

Seitanidou T, Triller A, Korn H (1988) Distribution of glycine receptors on the membrane of a central neuron: an immunoelectron microscopy study. J Neurosci 8:4319-4333.

Seitanidou T, Triller A, Korn H (1990) Redistribution of the 93kd protein associated with central glycine receptors, following denervation. Paper read at the $3 \mathrm{~d}$ conference of the Institute of Developmental Neuroscience and Aging (IDNA) in Torino, Italy.

Seitanidou T, Triller A, Korn H (1991) Immunohistochemical localization of glycine receptors and a linked polypeptide in the goldfish brain. J Receptor Res 11:359-370.

Somogyi P, Takagi H, Richards JG, Mohler H (1989) Subcellular localization of benzodiazepine/GABA $A_{A}$ receptors in the cerebellum of the rat and monkey using monoclonal antibodies. J Neurosci 9: 2197-2209.

Sotelo C (1968) Permanence of postsynaptic specializations in the frog sympathetic cells after denervation. Exp Brain Res 6:294-305.

St. John PH, Froehner SC, Goodenough DA, Cohen JB (1982) Nicotinic postsynaptic membranes from Torpedo: sideness, permeability and topography of major polypeptides. J Cell Biol 92:333-342.

Triller A, Korn H (1981) Morphologically distinct classes of inhibitory synapses arise from the same neurons: ultrastructural identification from crossed vestibular interneurons intracellularly stained with HRP. J Comp Neurol 203:131-155.

Triller A, Cluzeaud F, Pfeiffer F, Betz H, Korn H (1985) Distribution of glycine receptors at central synapses: an immunoelectron microscopy study. J Cell Biol 101:683-688.

Triller A, Cluzeaud F, Pfeiffer F, Korn H (1986) Distribution and transmembrane organisation of glycine receptors at central synapses: an immunocytochemical touch. In: Molecular aspects of neurobiology (Levi-Montalcini R, Calissano P, Kandel ER, Maggi A, eds), pp 101105. Berlin: Springer.

Triller A, Seitanidou T, Franksson O, Korn H (1990) Size and shape of glycine receptor clusters in a central neuron exhibit a somatodendritic gradient. New Biol 2:637-341.

Van den Pol A, Gorcs T (1988) Glycine and glycine receptor immunoreactivity in brain and spinal cord. J Neurosci 8:472-492.

Wood MR, Faber DS (1986) Electrophysiological and morphological correlates of axotomy-induced deafferentation of the goldfish Mauthner cell. J Comp Neurol 244:413-429.

Young AB, Snyder SH (1973) Strychnine binding associated with glycine receptors of the central nervous system. Proc Natl Acad Sci USA 70:2832-2836.

Young AB, Snyder SH (1974) The glycine synaptic receptor: evidence that strychnine binding is associated with the ionic conductance mechanism. Proc Natl Acad Sci USA 71:4002-4005.

Zottoli SJ, Faber DS (1980) An identifiable class of statoacoustic interneurons with bilateral projections in the goldfish medulla. Neuroscience 5:1287-1302.

Zottoli SJ, Hangen DH, Faber DS (1984) The axon reaction of the goldfish Mauthner cell and factors that influence its morphological variability. J Comp Neurol 230:497-516. 